\title{
Morphosyntactical Representation in Kurdish Language
}

\author{
Abduljabar Mustafa MAROOF ${ }^{1}$ \& Sazan Zahir SAEED ${ }^{2}$
}

Received: Nov 30, 2017 Reviewed: Dec 31, 2017 Accepted: Jan 08, 2018

\begin{abstract}
This study entitled (Morphosyntactical Representation in Kurdish Language) is an attempt to identify those mechanisms that produce morphosyntactic units. This is by showing the the steps of building the project and how they are applied based on theories that govern syntactic connections. From this perspective, the study uses the examples and their analyses as experimental evidence to answer these questions: does morphosyntax as a pre-sentence manifestation project need to pass all the syntactic and semantic components the way a sentence project needs to? Or is it a different syntactically produced project? By syntactic and semantic components, it is meant those that are there within Projection Principle and Extended Projection Principle.
\end{abstract}

Keywords: Morphosyntax, Projection, Deletion Rules, Copy, Movement, Semantic Selection .

Recommended citation:

Maroof, A.M. \& Saeed, S.Z. (2018). Morphosyntactical Representation in Kurdish Language. International Journal of Kurdish Studies 4 (1), 233 -251, DOI: 10.21600/ijoks.383403

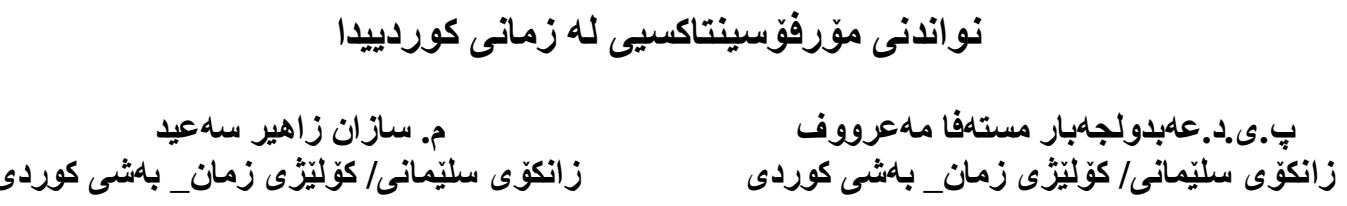

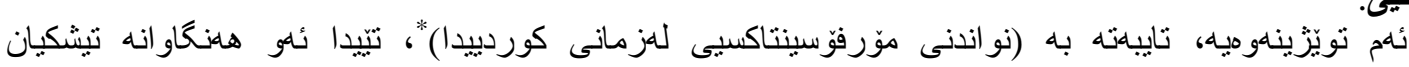

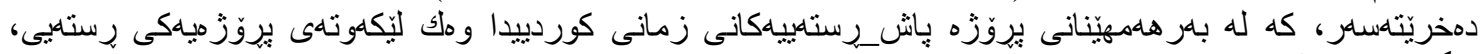

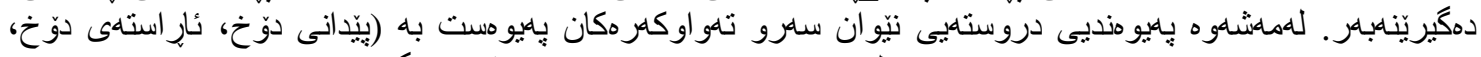

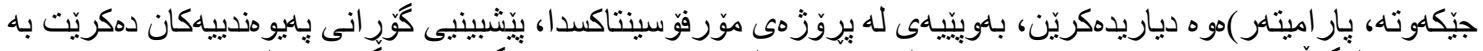

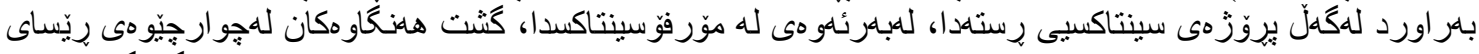

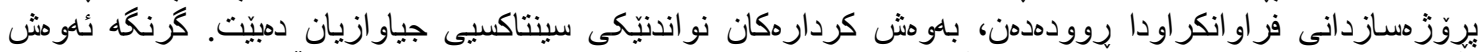

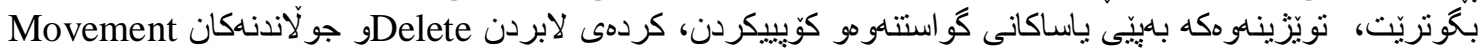

${ }^{1}$ Asst. Prof. Dr., Department of Kurdish Language/ College of Language/ Language \& Humanities/ University of Sulaimani. Kurdistan Region - Iraq. E-mail: abduljabar.maroof@univsul.edu.iq

${ }^{2}$ Lecturer- Phd Student. Department of Kurdish Language/ College of Language/ Language \& Humanities/ University of Sulaimani. Kurdistan Region - Iraq. E-mail: sazan.mohammad@univsul.edu.iq

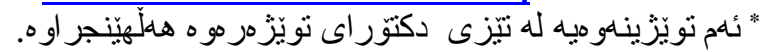

International Journal of Kurdish Studies Vol.4/1 ( January 2018) 


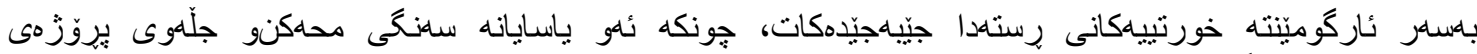

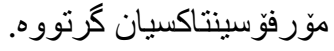

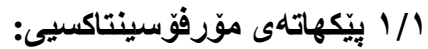

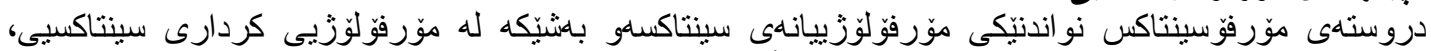

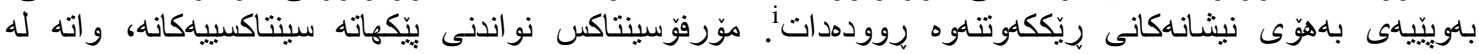

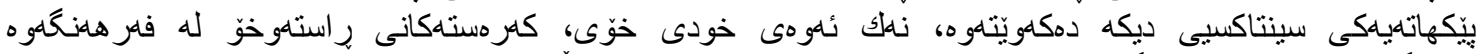

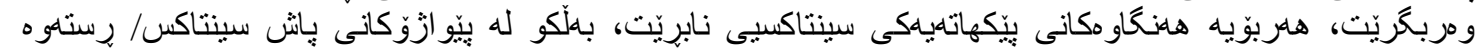

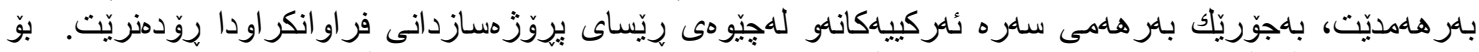

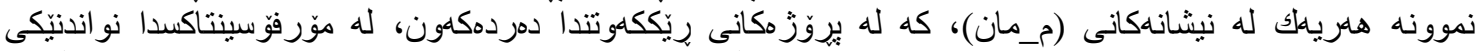

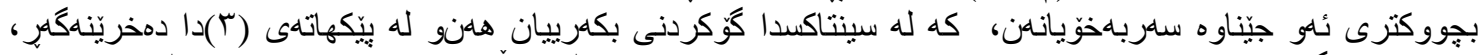

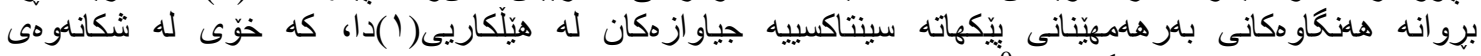

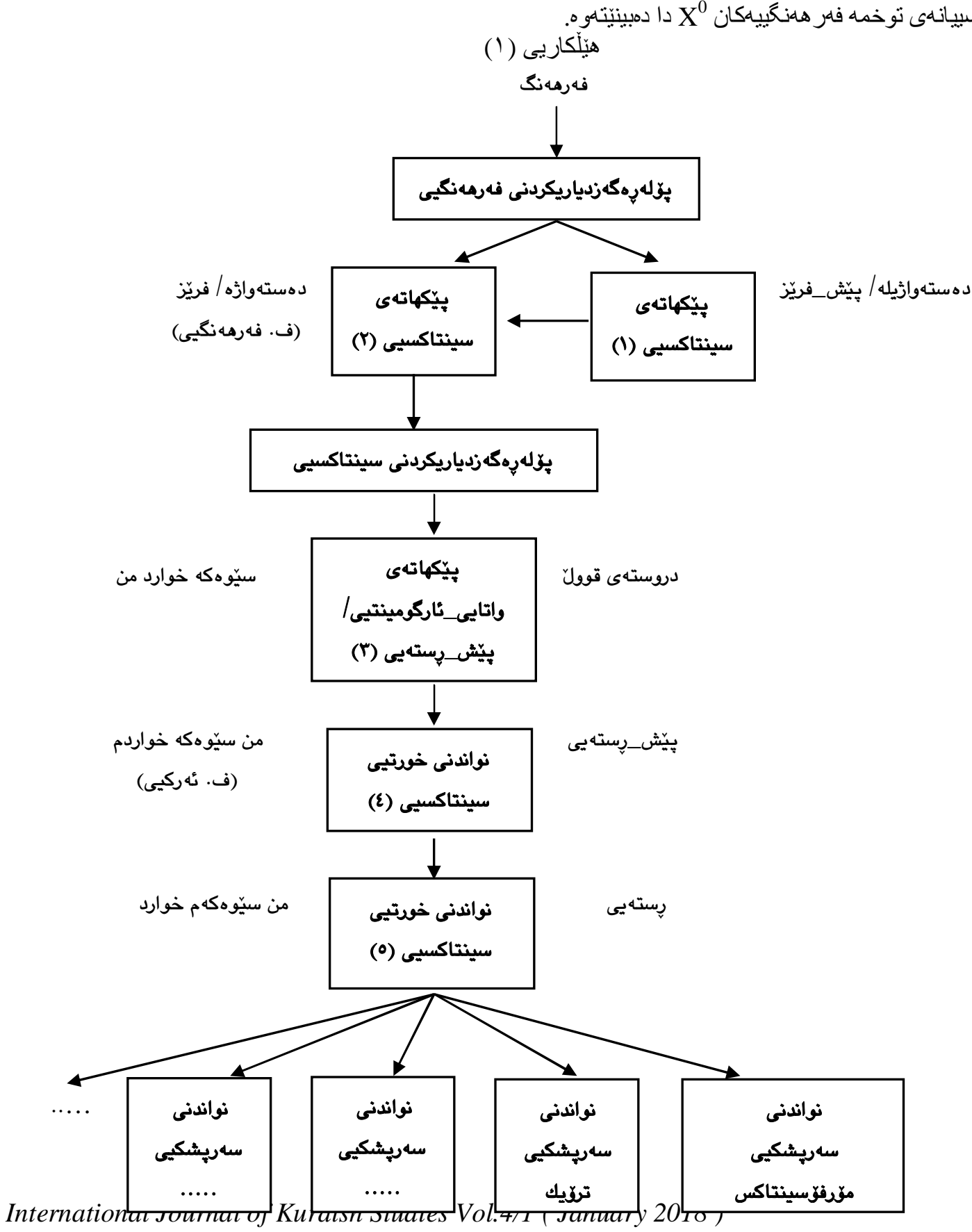




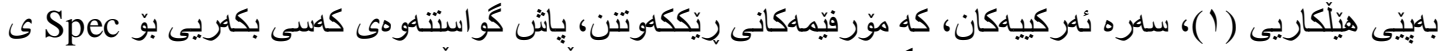

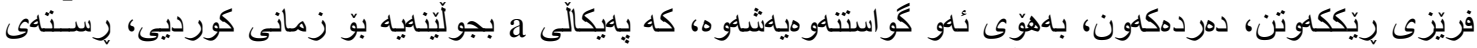

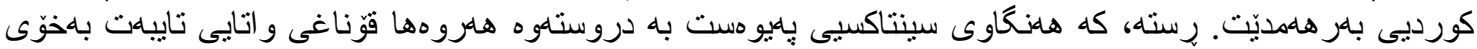

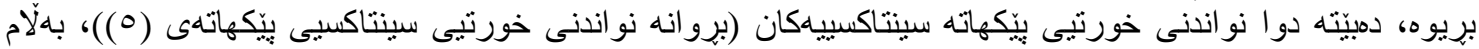

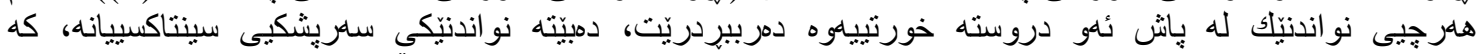

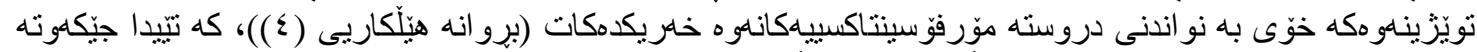

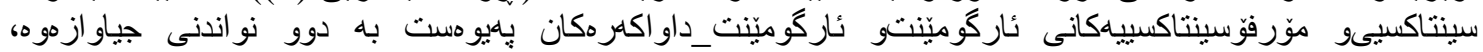
دهستنيشانكر اون.

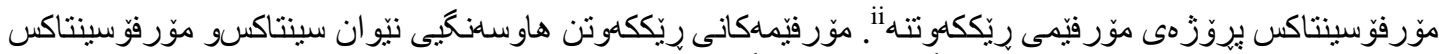

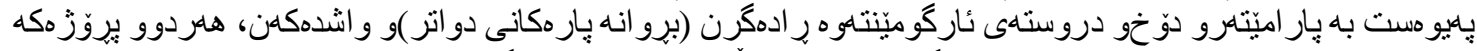

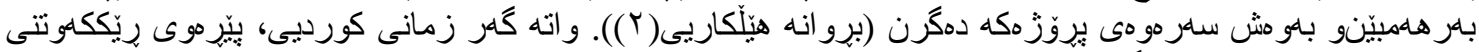

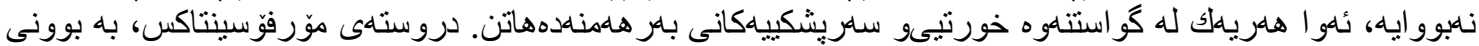

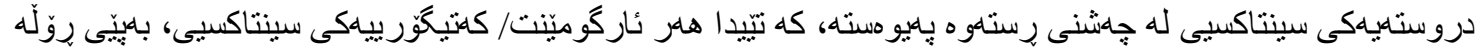

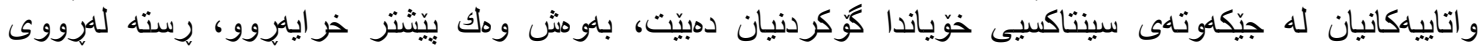

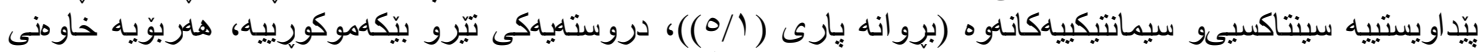

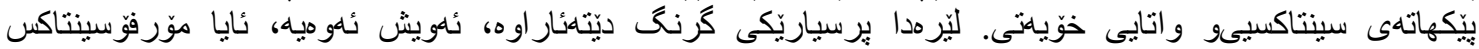

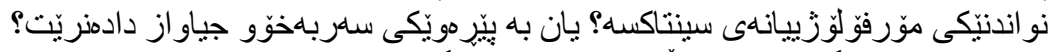

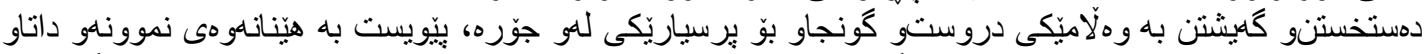

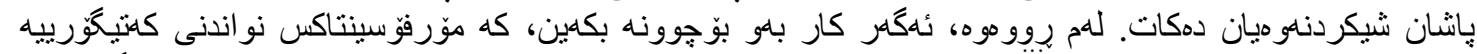

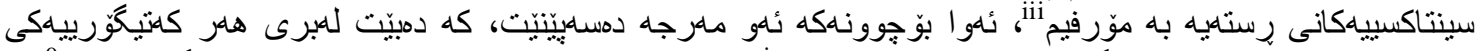

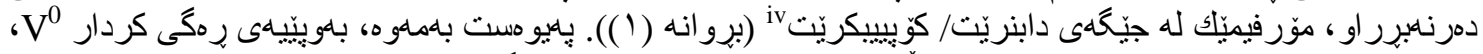

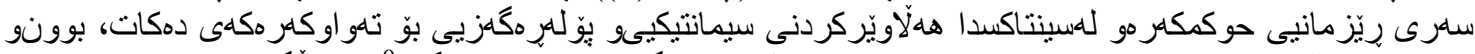

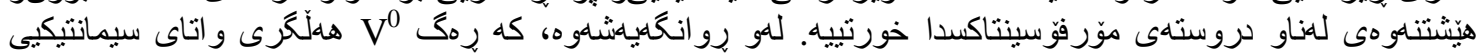

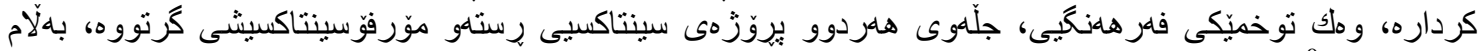

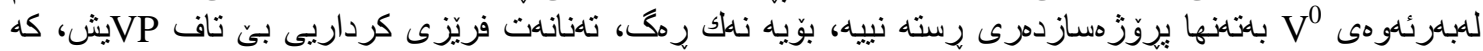

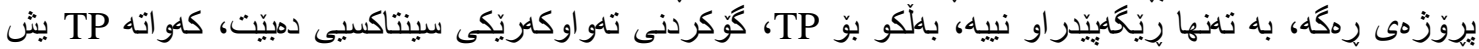

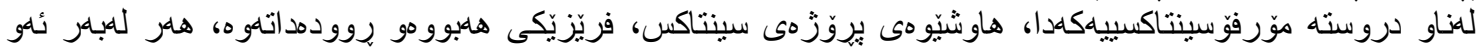

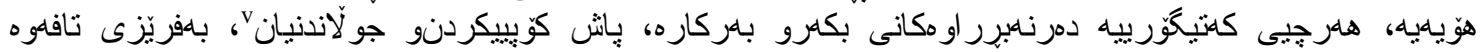

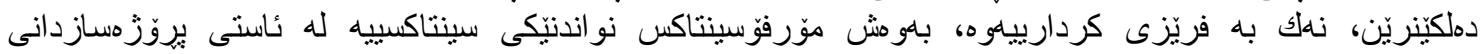

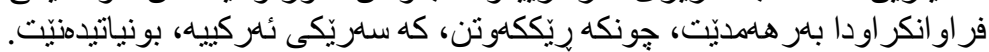

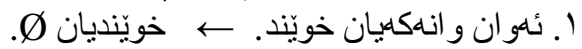

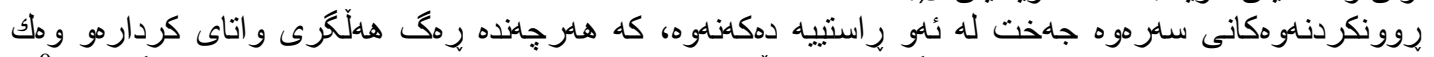

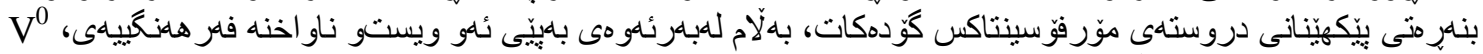

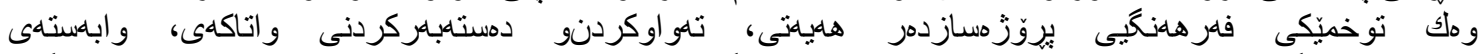

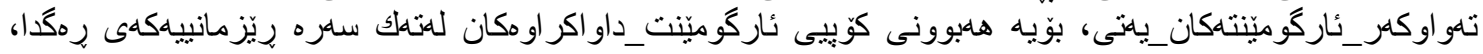

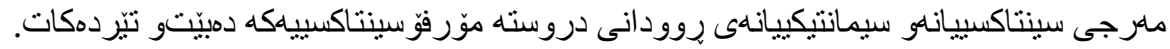

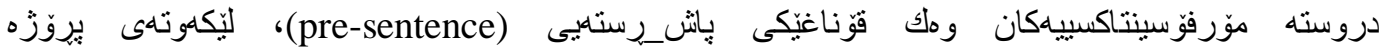

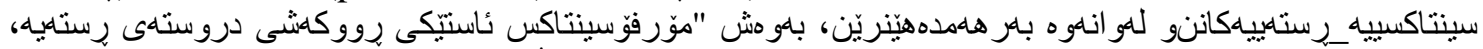

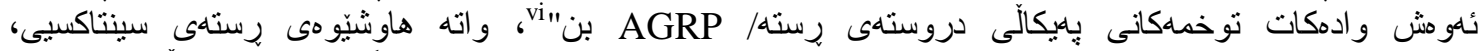

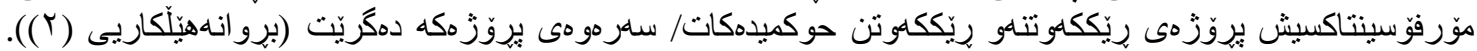

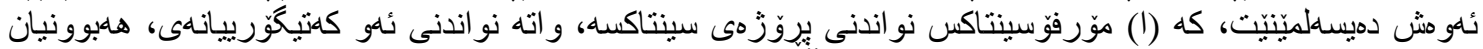

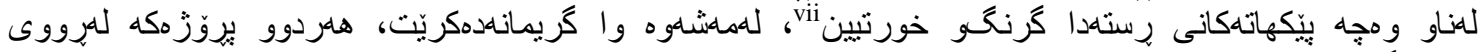

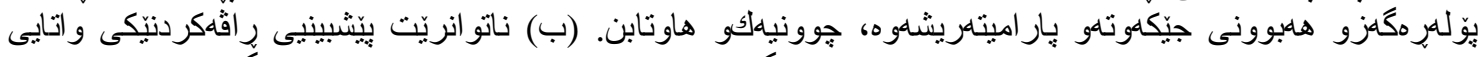

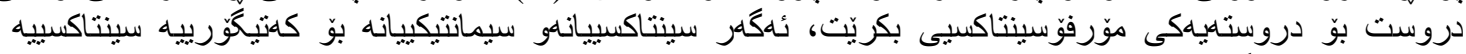

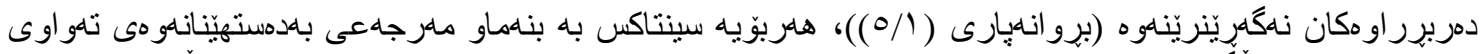

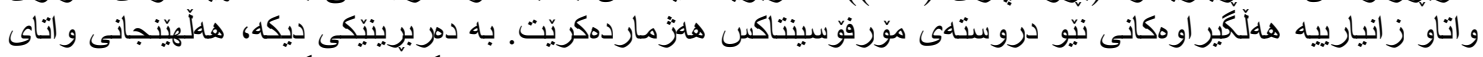

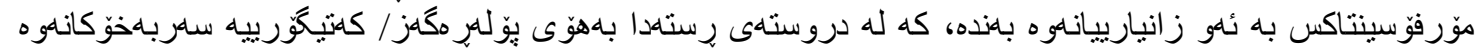

International Journal of Kurdish Studies Vol.4/1 ( January 2018) 


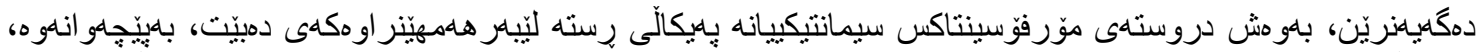

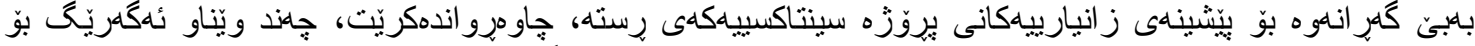

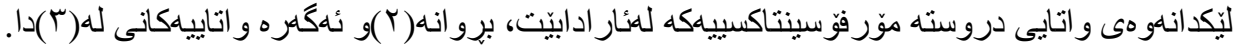

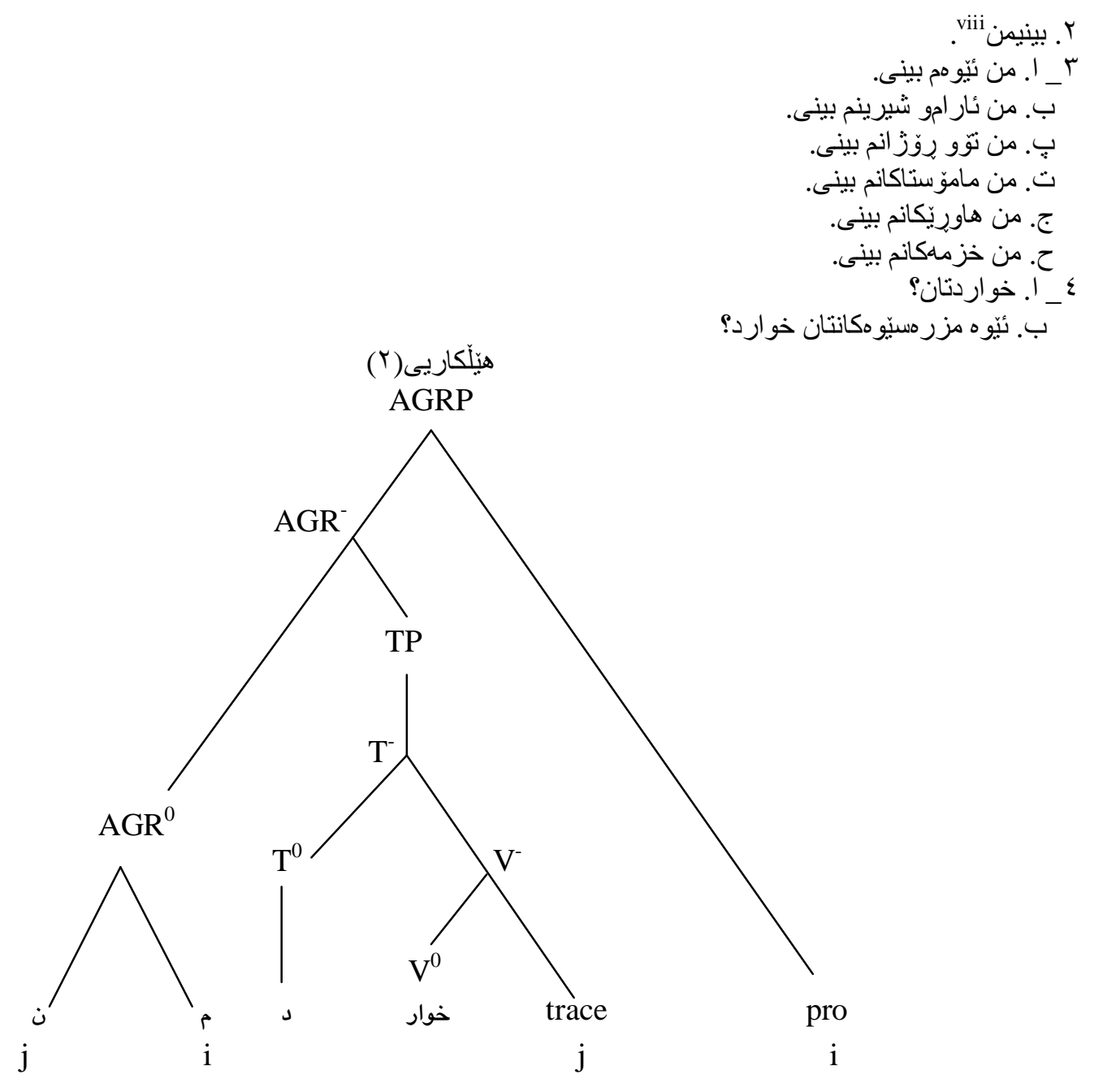

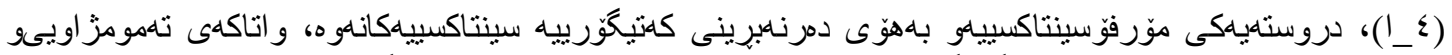

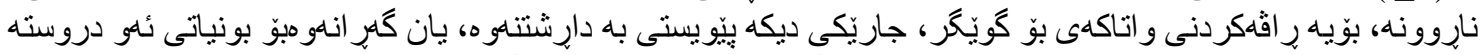

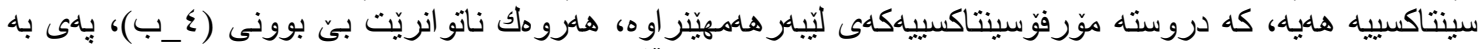

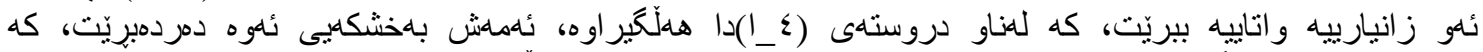

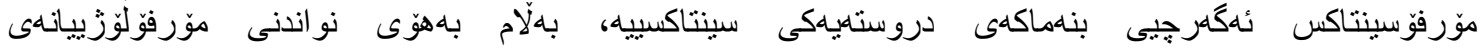

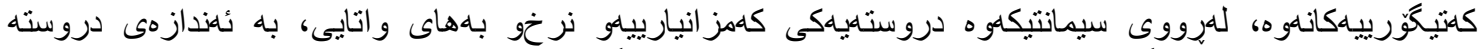

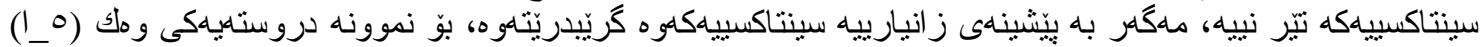

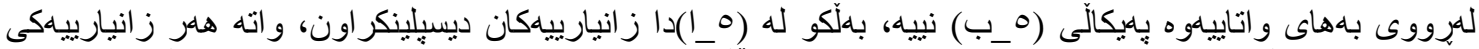

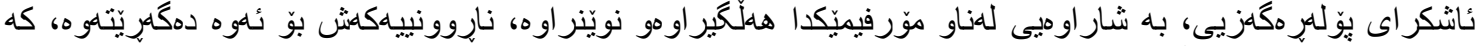

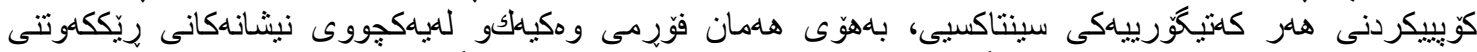

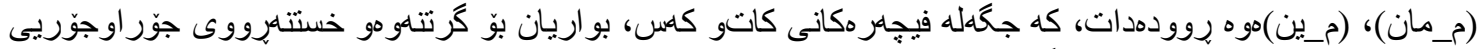

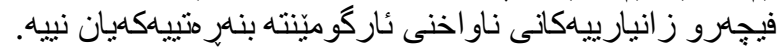

$$
\text { بـ ب. من نهمامهكانم يرو اند. }
$$




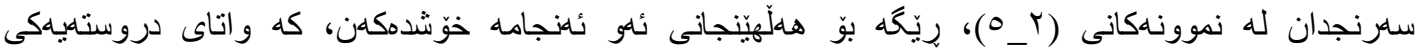

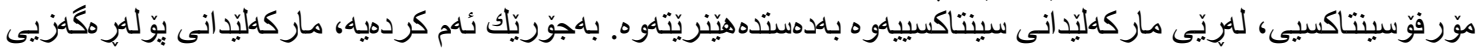

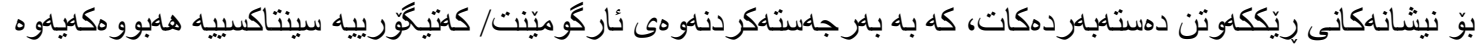

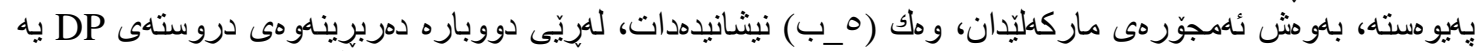

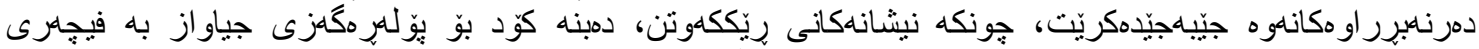

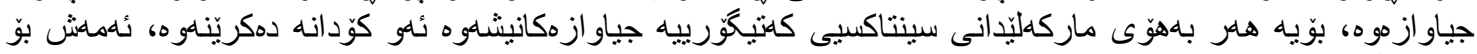

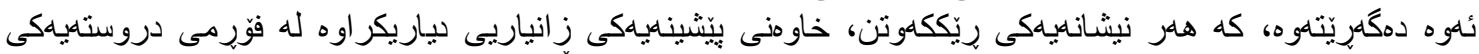

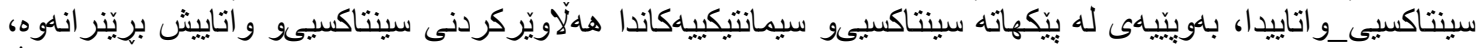

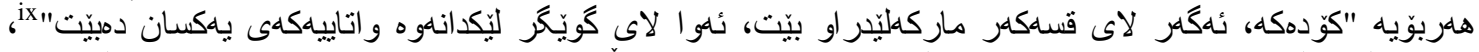

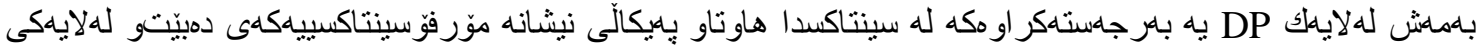

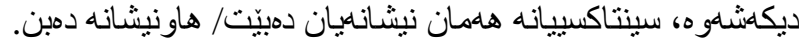

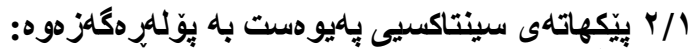

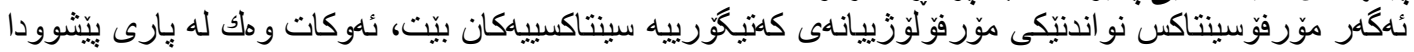

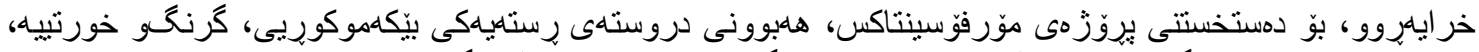

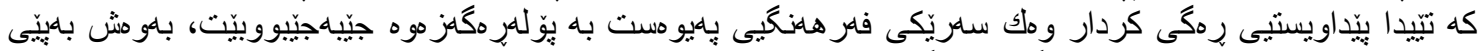

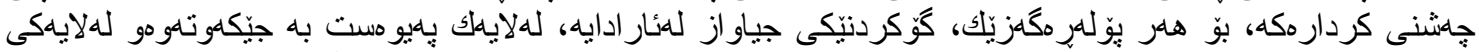

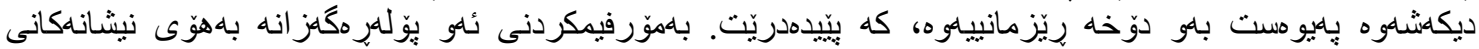

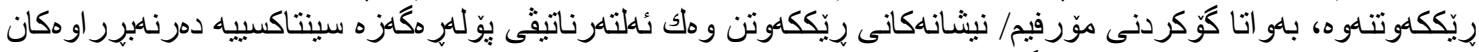

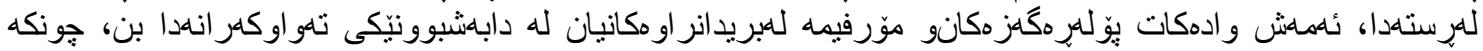

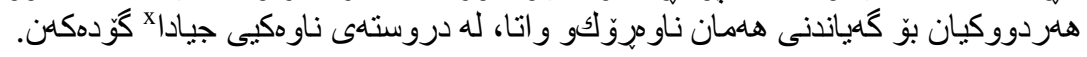

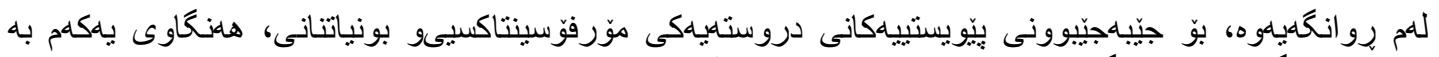

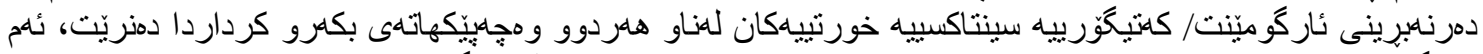

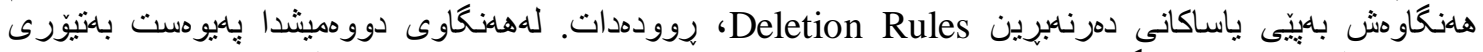

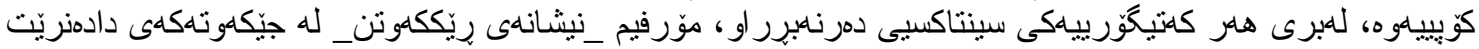

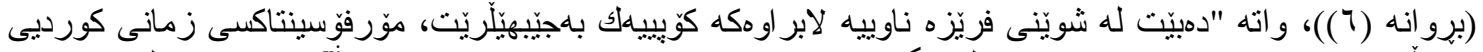

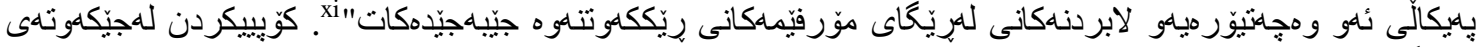

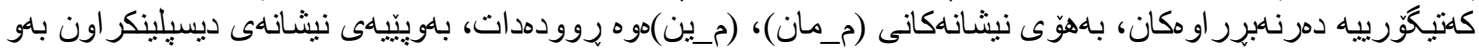

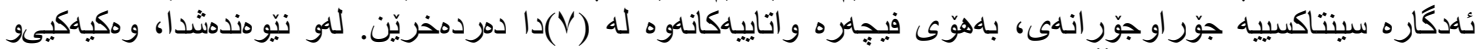

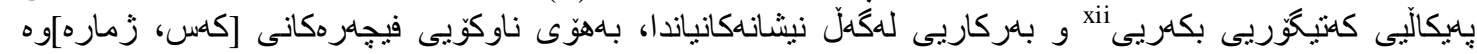

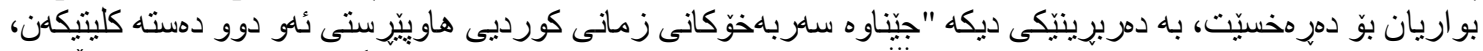

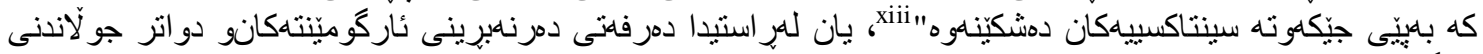

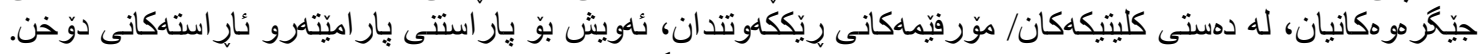

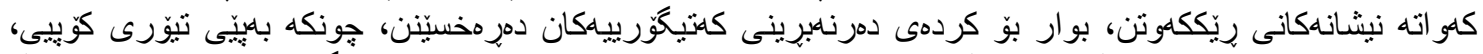

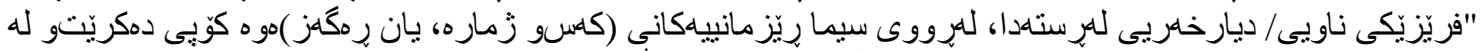

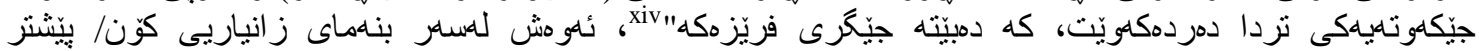

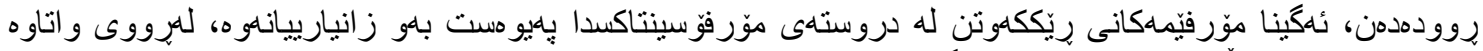

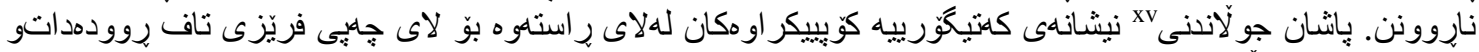

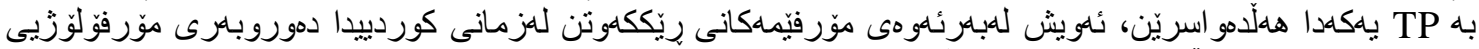

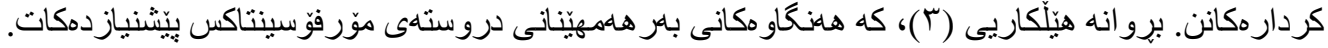

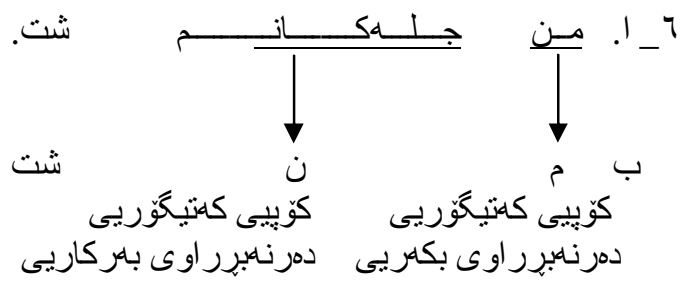

International Journal of Kurdish Studies Vol.4/1 ( January 2018) 


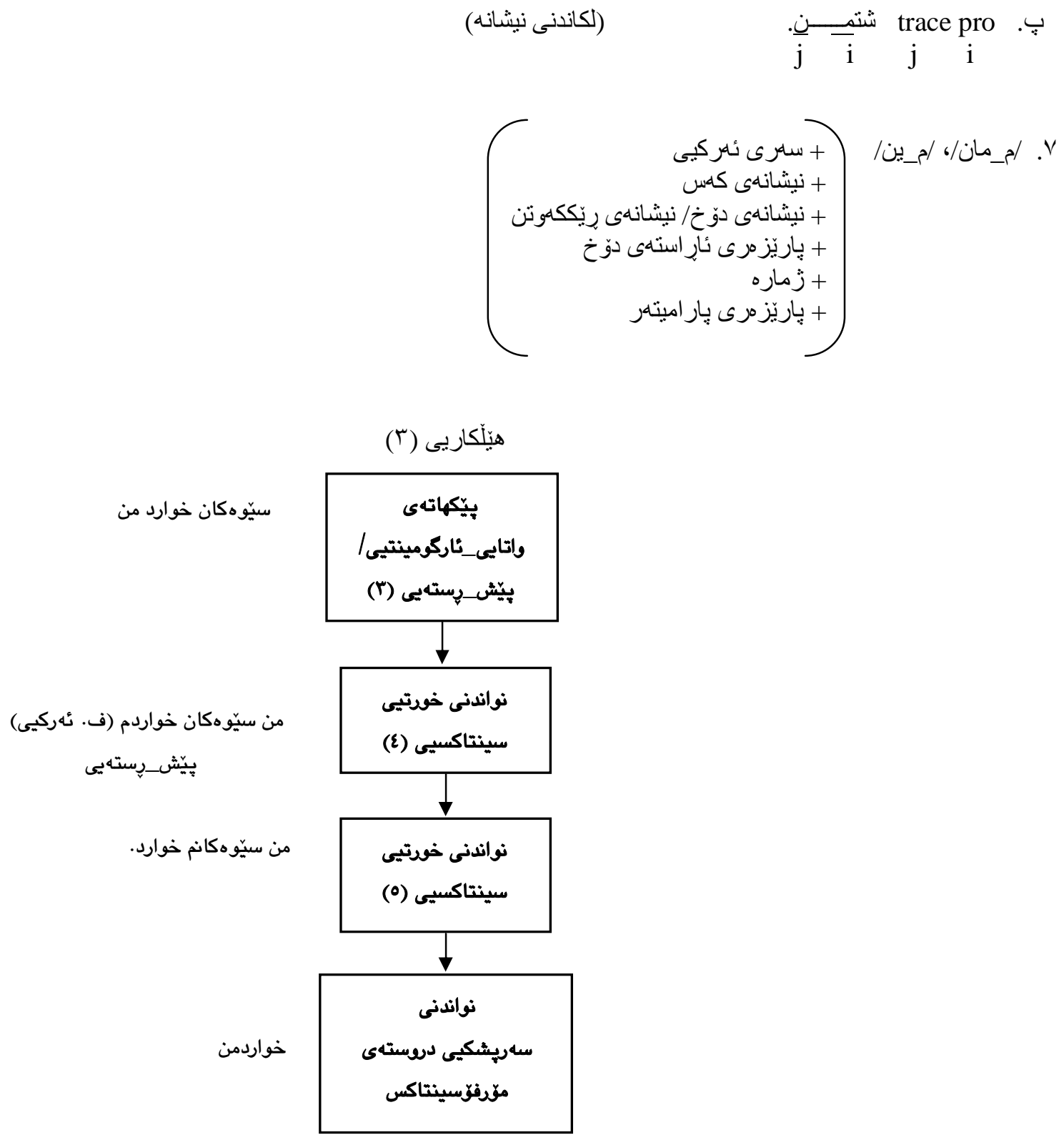

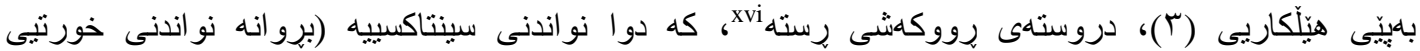

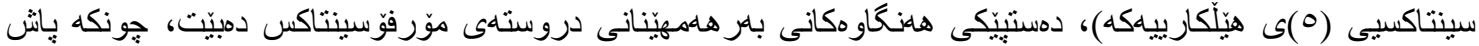

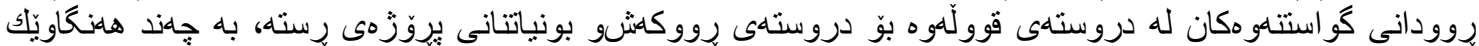

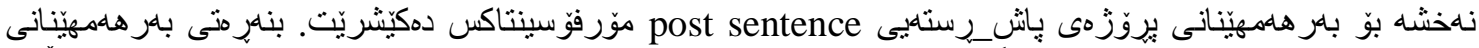

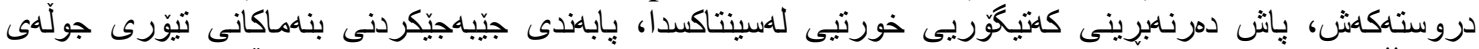

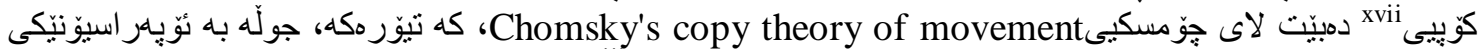

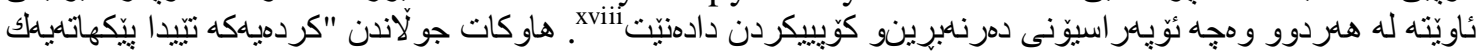

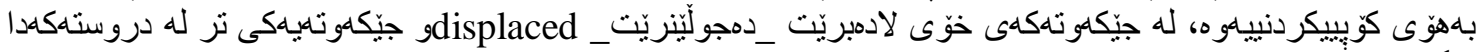

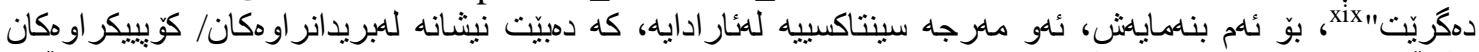

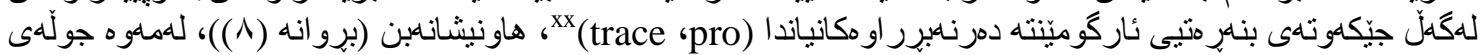

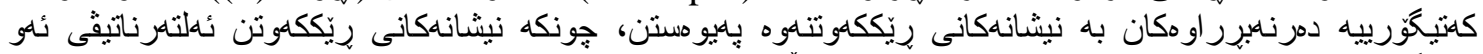

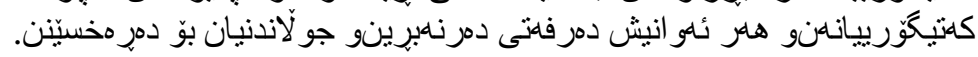




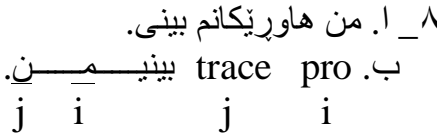

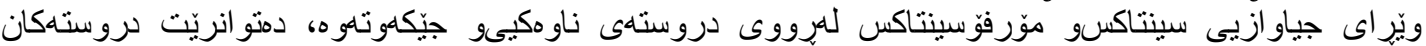

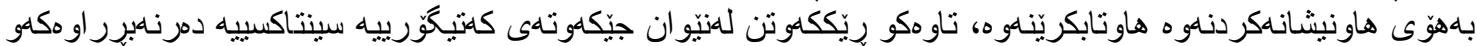

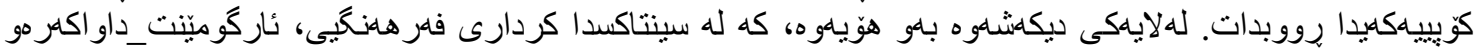

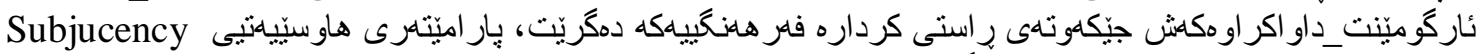

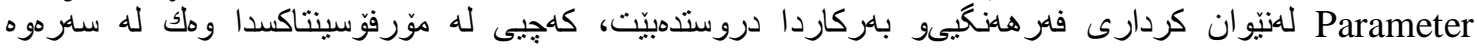

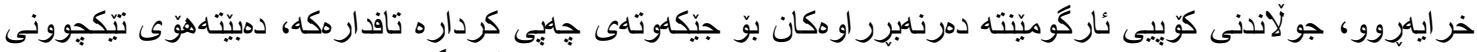

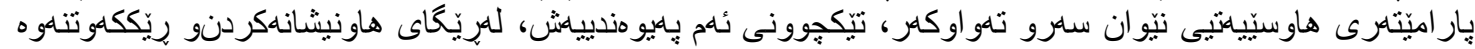

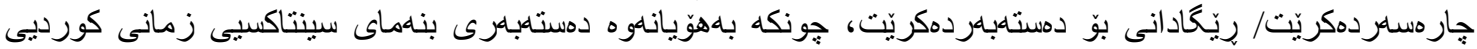

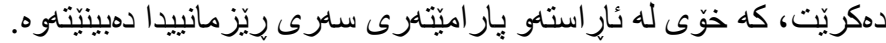

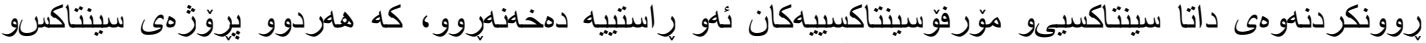

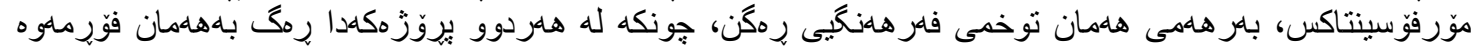

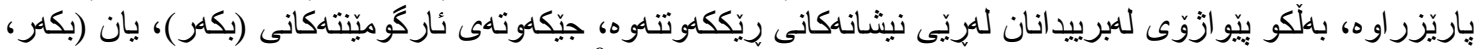

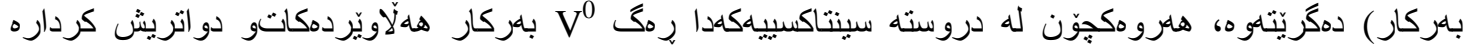

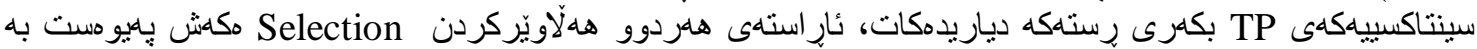

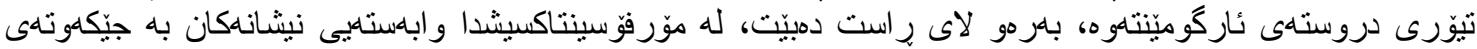

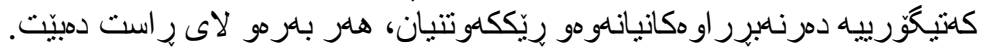

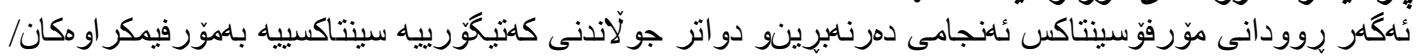

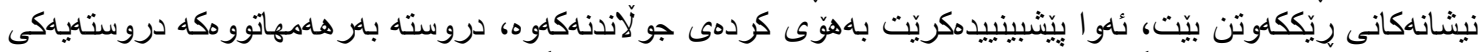

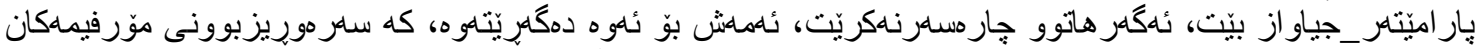

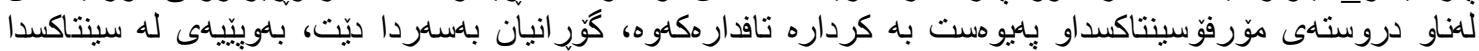

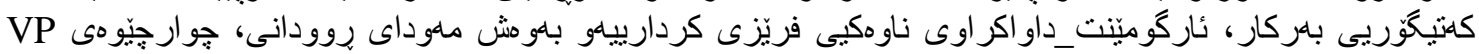

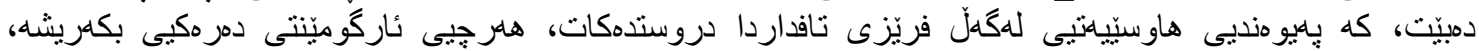

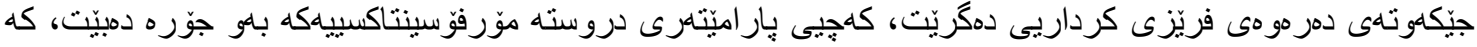

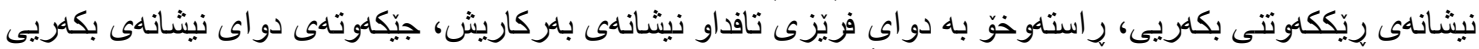

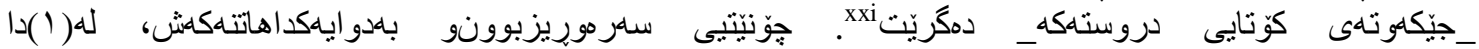

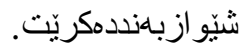

$$
\text { ــ كردارى تافدار (فريزى تاف) + نيشانهى ريككهوتنى بكهريى + نيشانهى بهركار }
$$

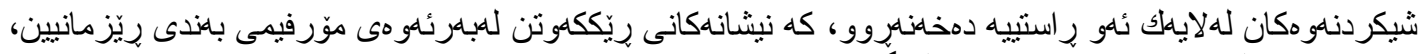

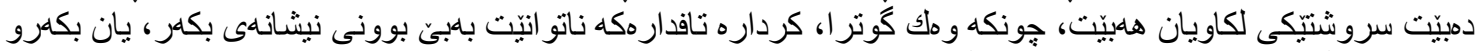

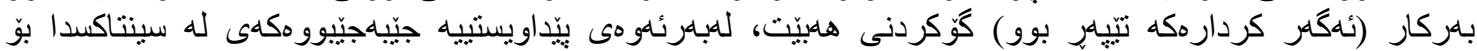

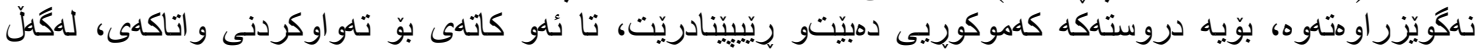

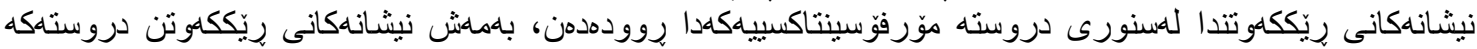

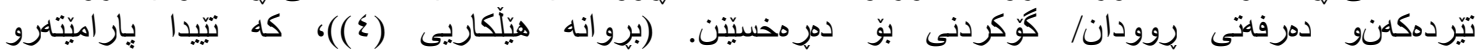

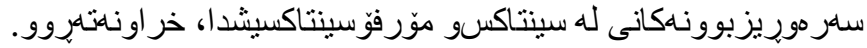

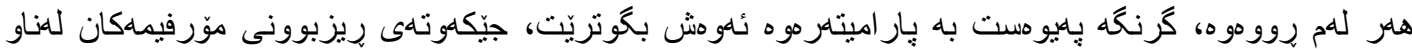

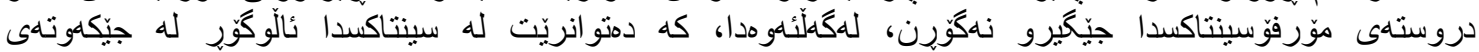

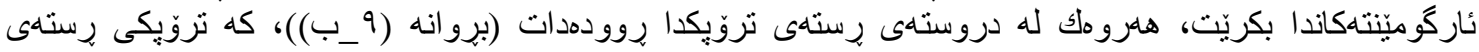

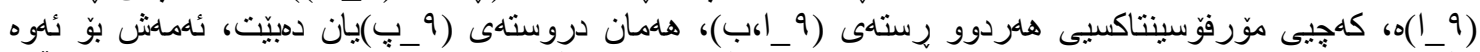

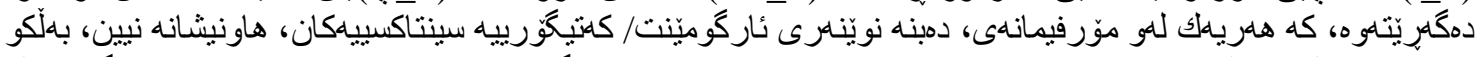

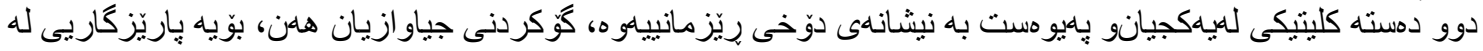
جيّكهوتنهى يروودانيان دمكهن. 


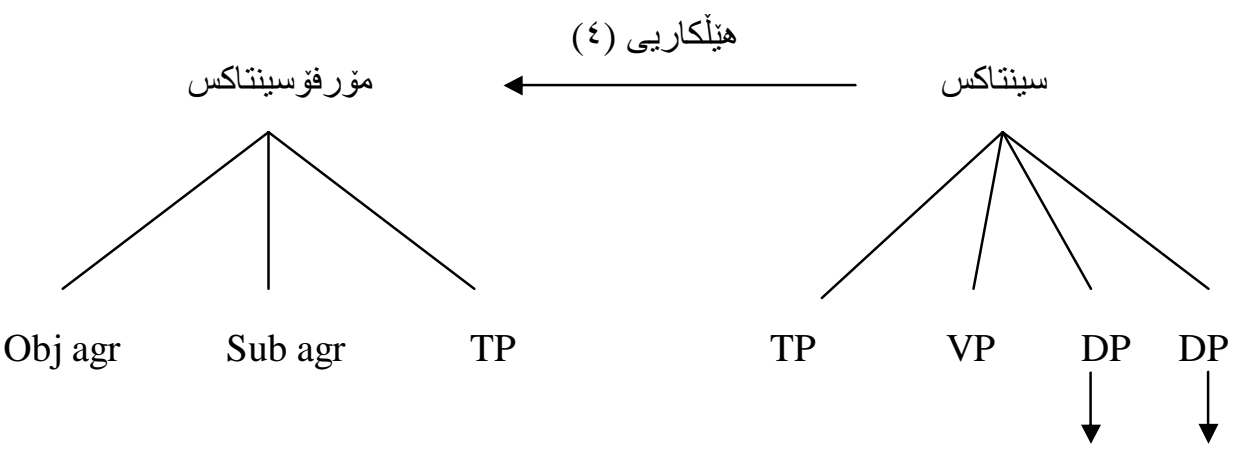

Obj. Sub.

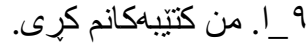

$$
\begin{aligned}
& \text { ب. كتينيكان، من t كريمن. } \\
& \text { ب. ب. كريمن. }
\end{aligned}
$$

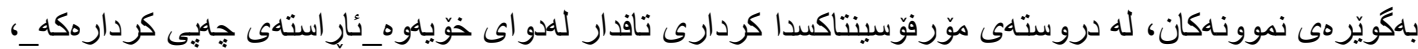

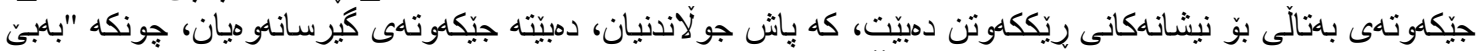

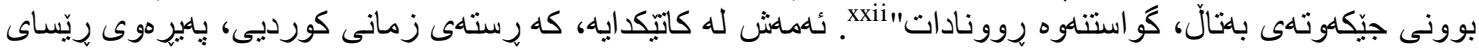

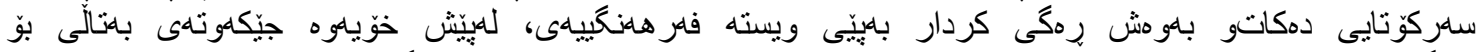

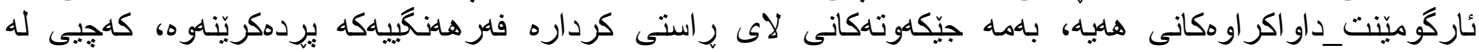

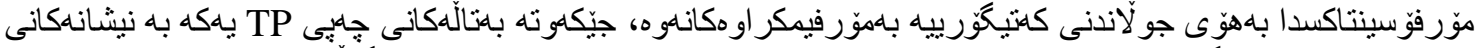

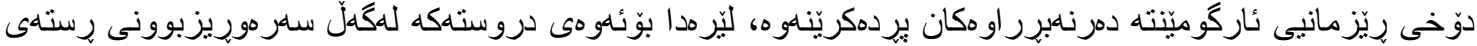

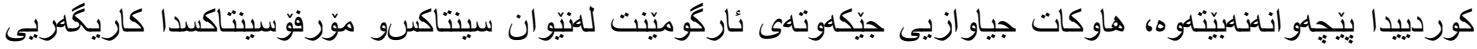

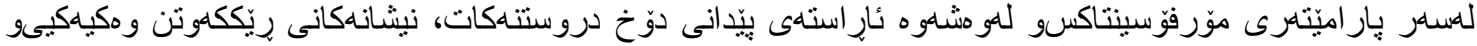

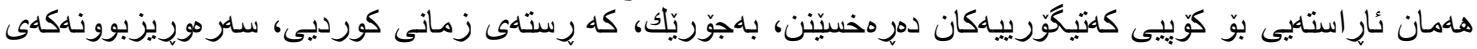

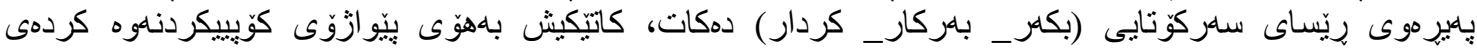

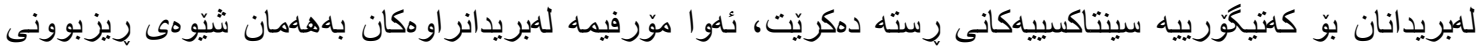

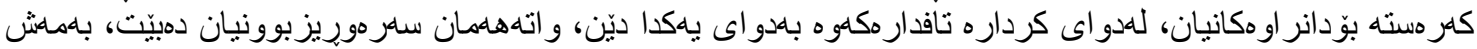

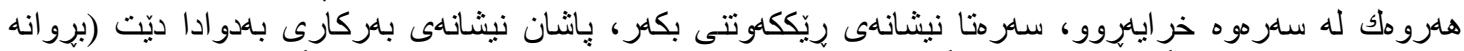

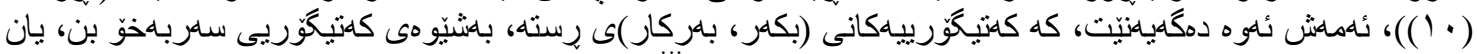

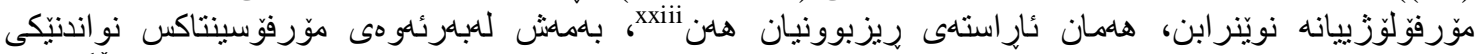

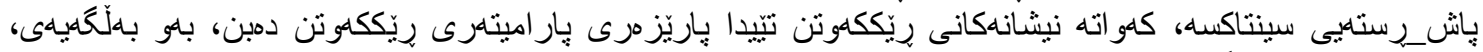

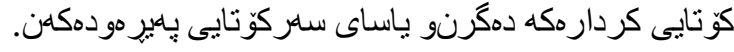

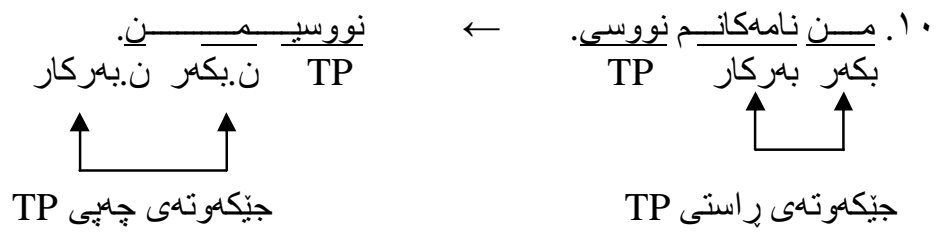

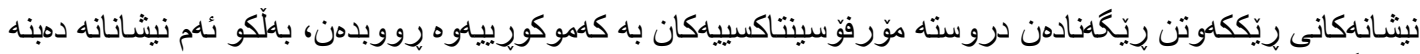

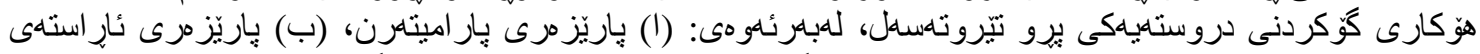

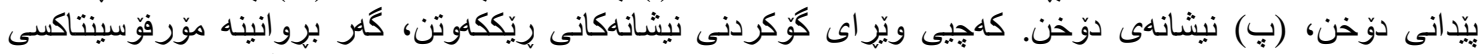

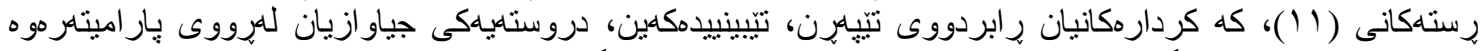

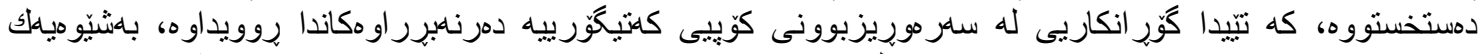

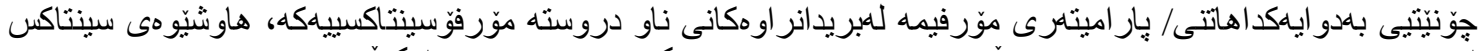

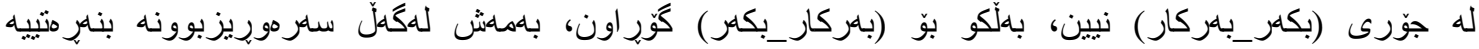




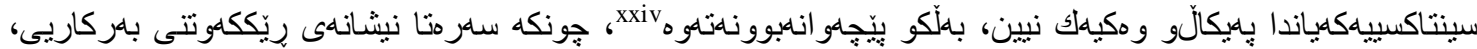

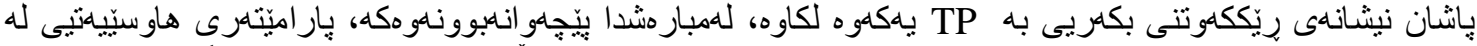

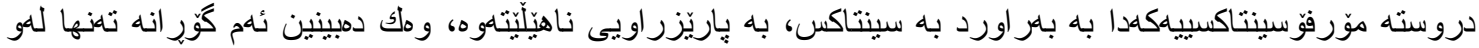

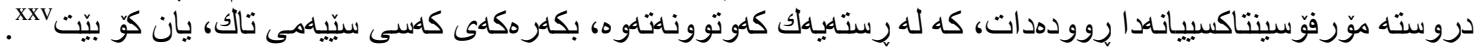

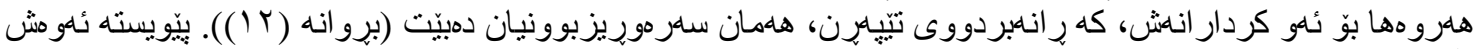

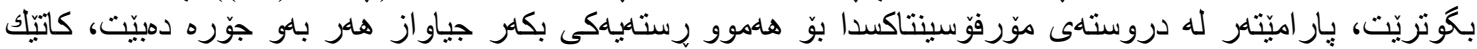

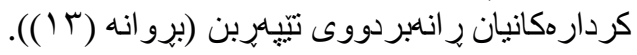

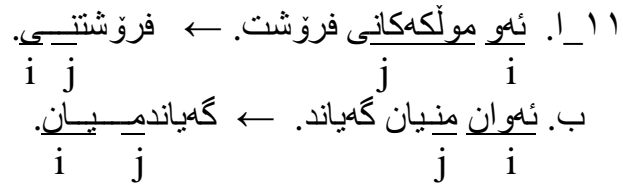

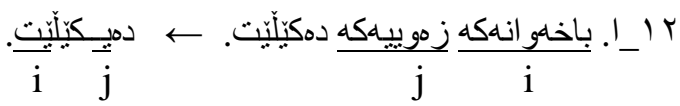

$$
\begin{aligned}
& \text { ب. ئهو ان دار كان دمبرنهوه. }
\end{aligned}
$$

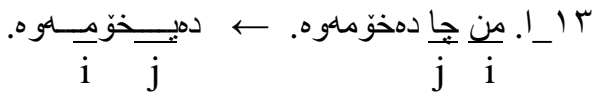

$$
\begin{aligned}
& \text { ب }
\end{aligned}
$$

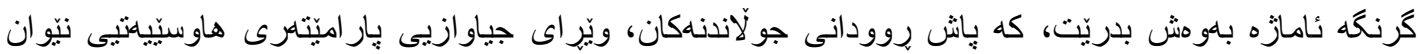

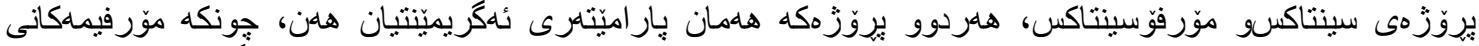

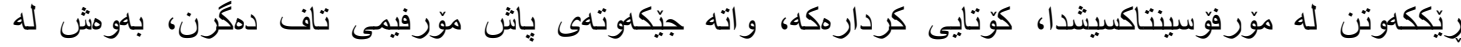

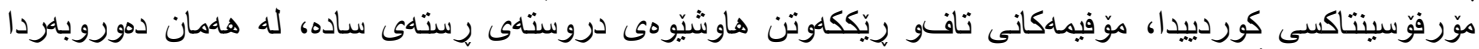

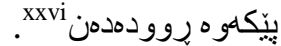

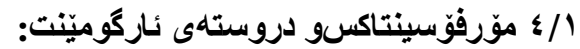

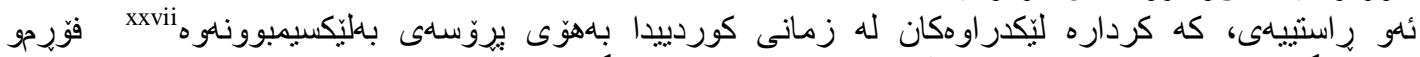

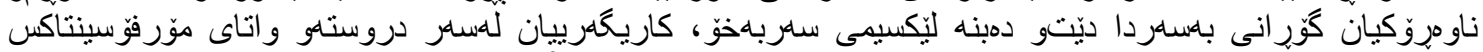

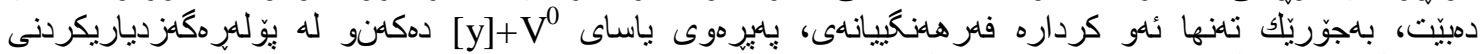

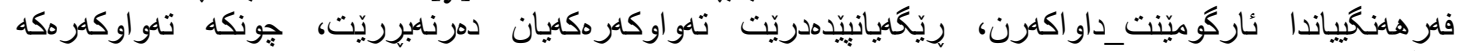

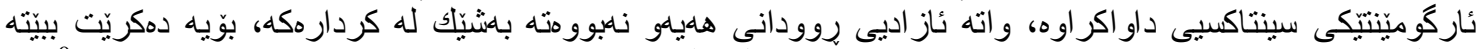

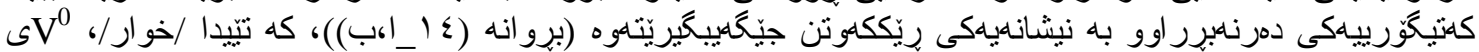

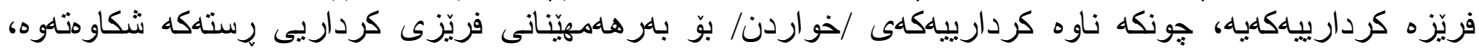

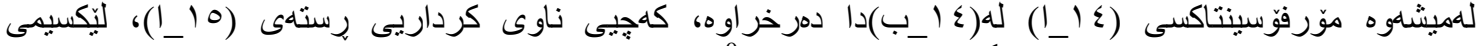

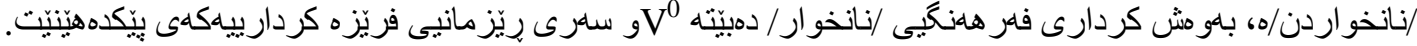

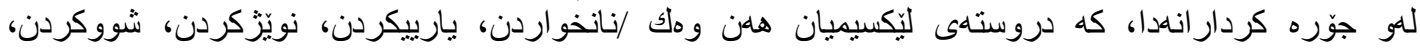

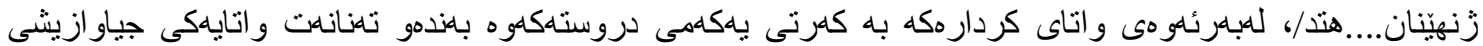

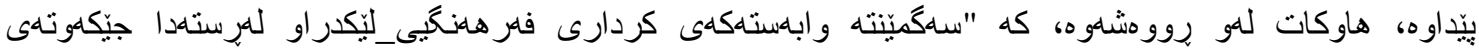

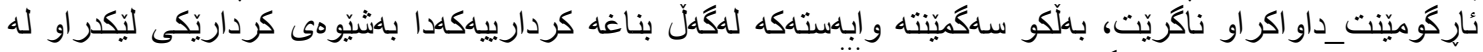

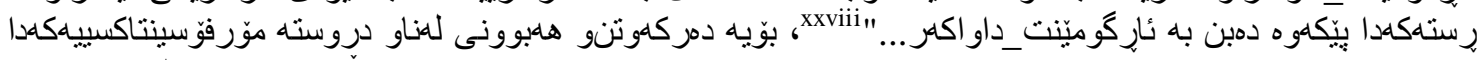

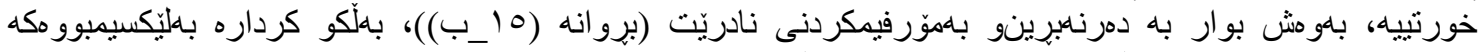

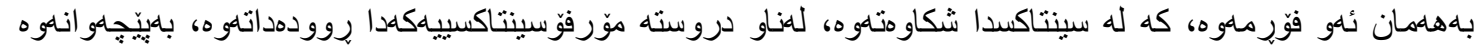

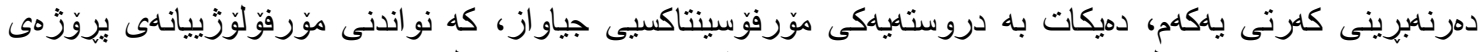

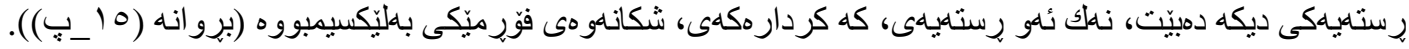




$$
\begin{aligned}
& \text { ع ا ــ ــ من نانم خوارد. /خواردن/ }
\end{aligned}
$$

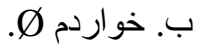

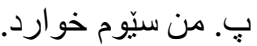

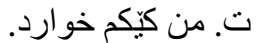

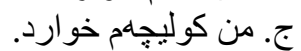

$$
\begin{aligned}
& 10
\end{aligned}
$$

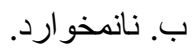

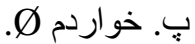

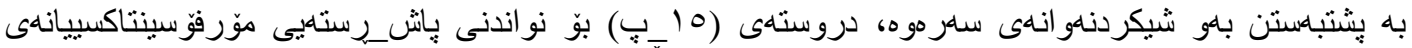

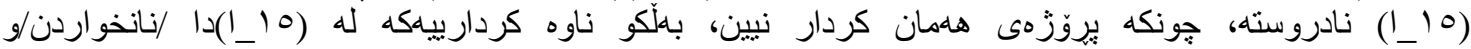

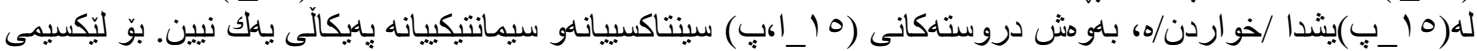

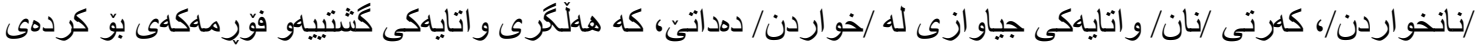

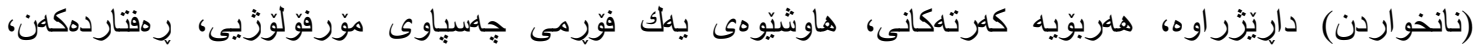

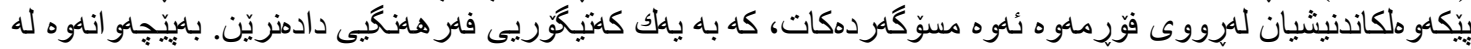

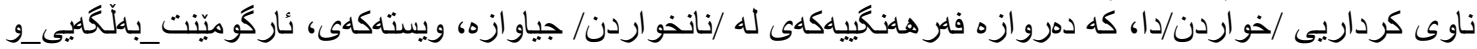

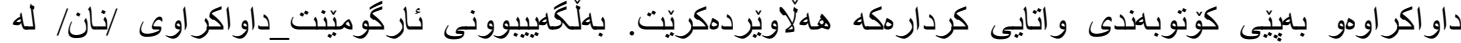

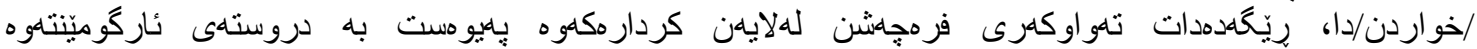

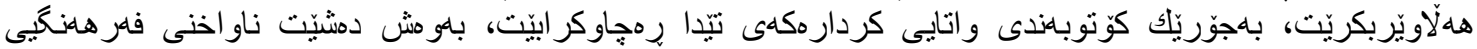

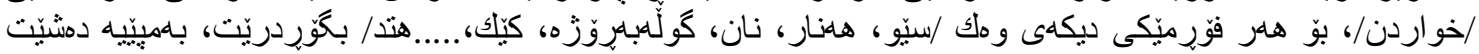

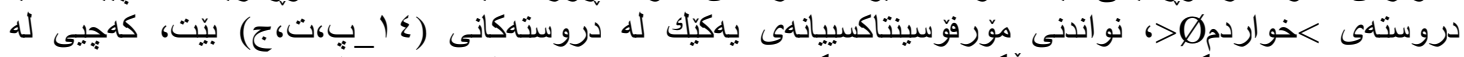

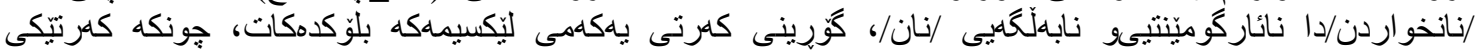

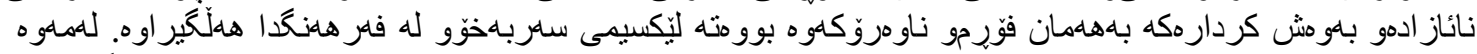

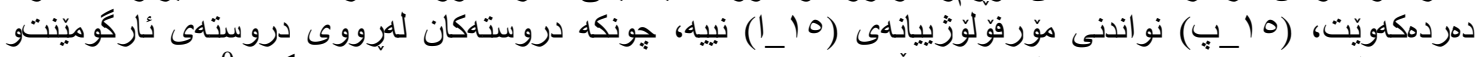

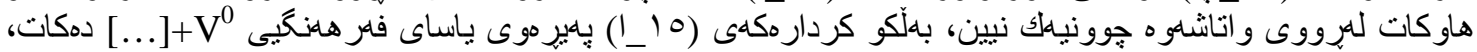

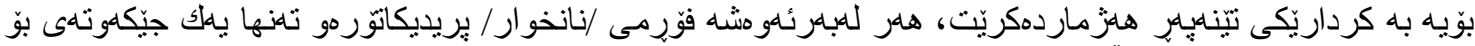

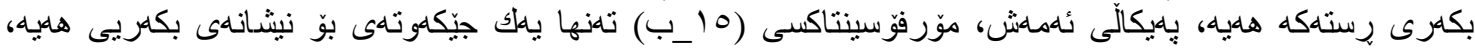

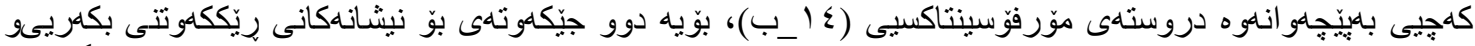

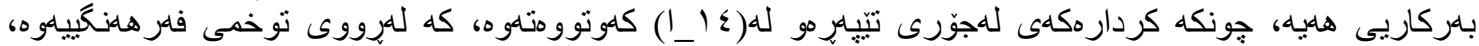

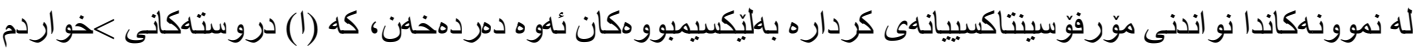

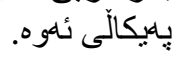

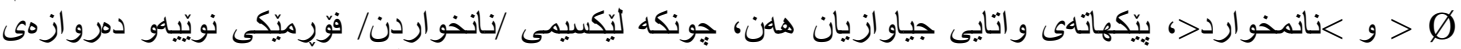

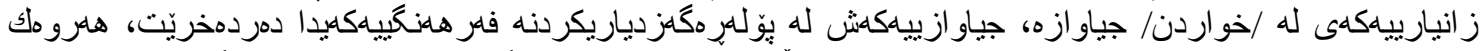

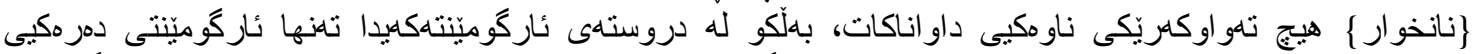

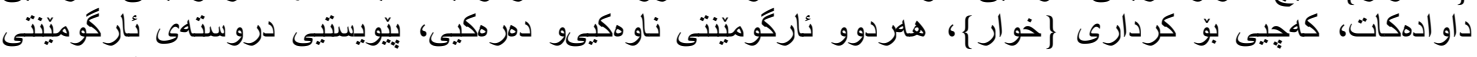

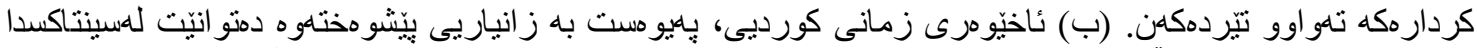

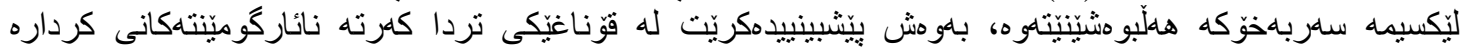

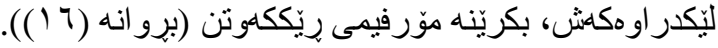

$$
\begin{aligned}
& \text { 17_ا_. ناوز ادزنيهيناوه. /ذّنهينان/ }
\end{aligned}
$$

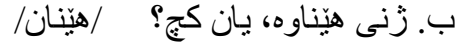

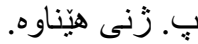

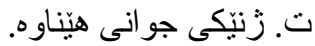

$$
\begin{aligned}
& \text { ج. زُنبّكى باشو خانهدانى هينّاوه. }
\end{aligned}
$$

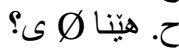

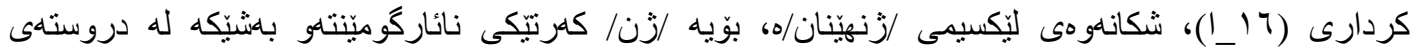

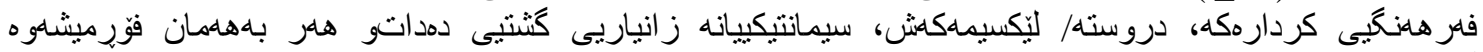

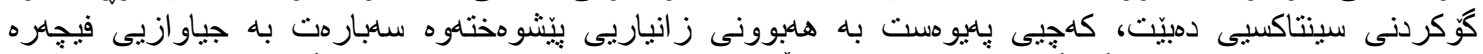

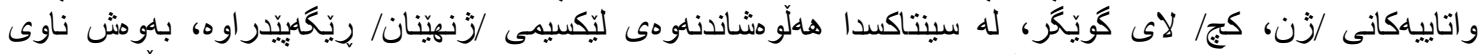

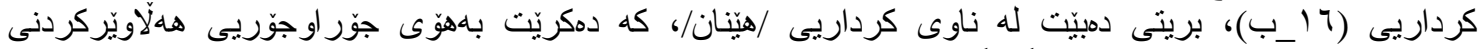

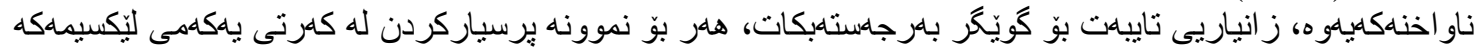




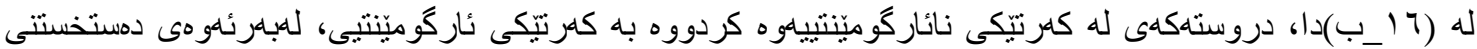

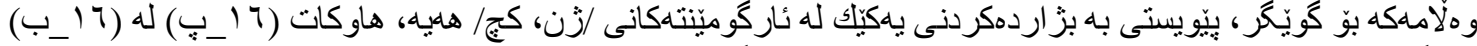

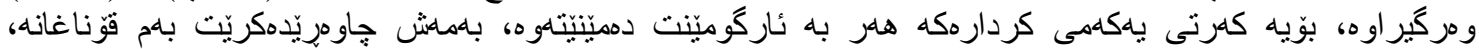

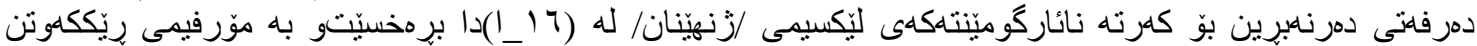

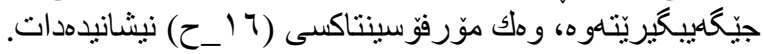

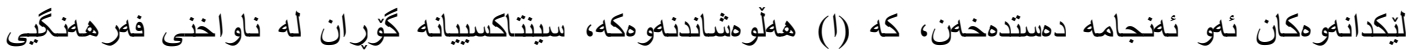

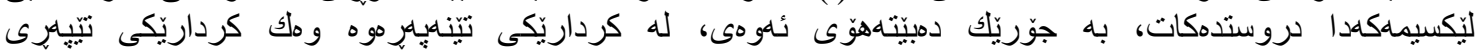

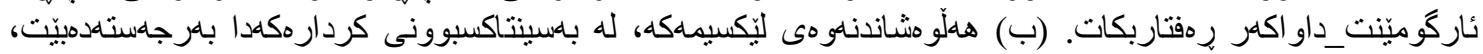

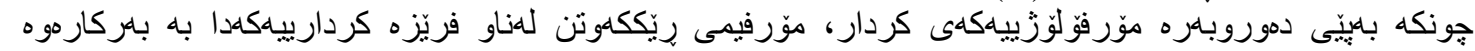

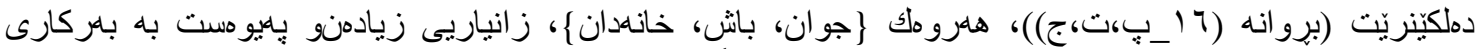

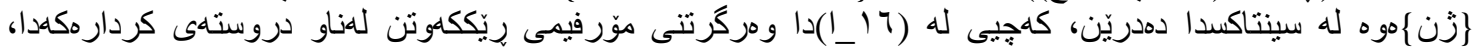

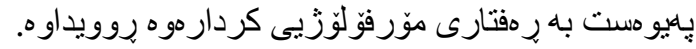

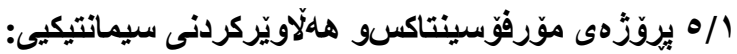

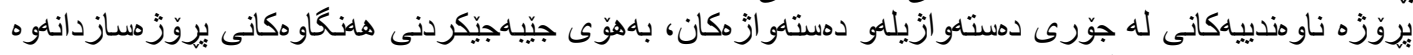

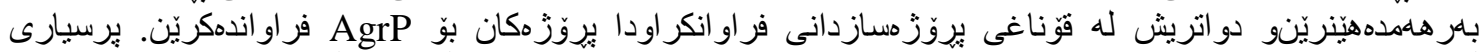

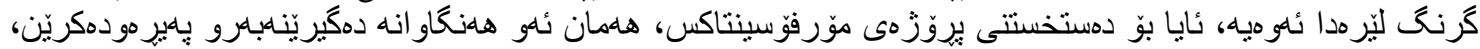

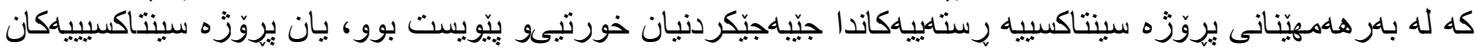

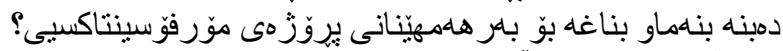

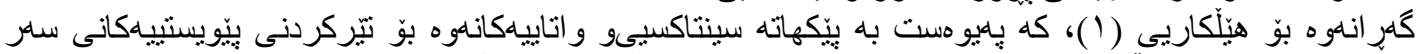

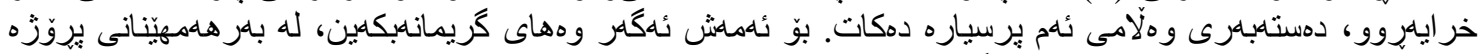

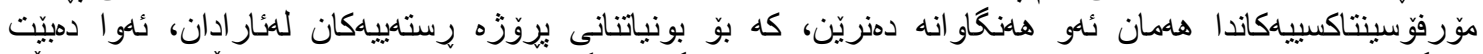

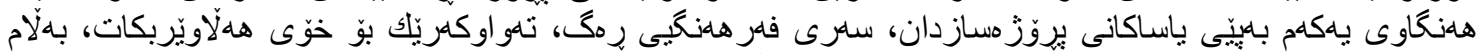

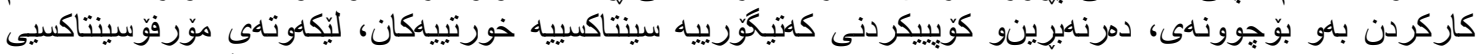

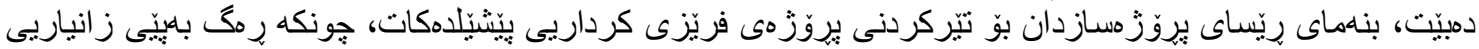

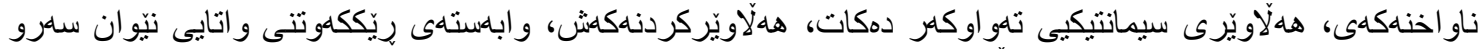

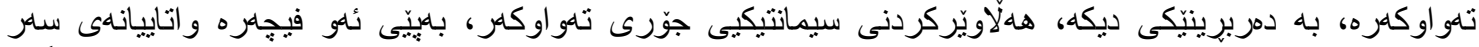

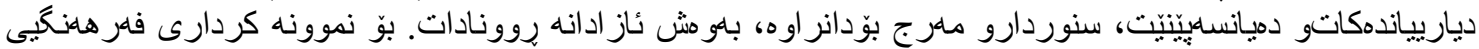

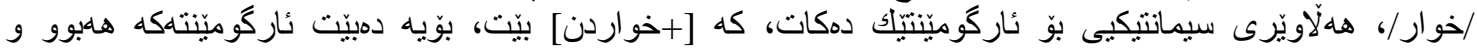

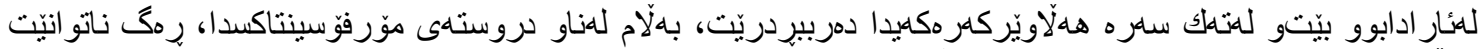

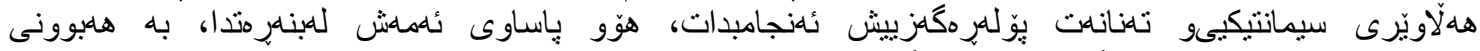

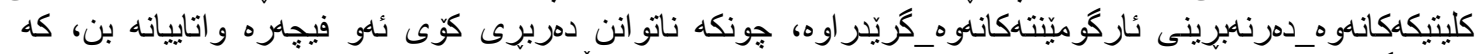

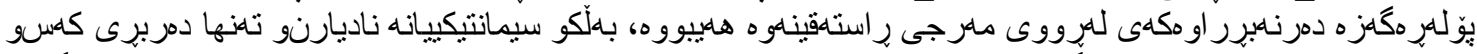

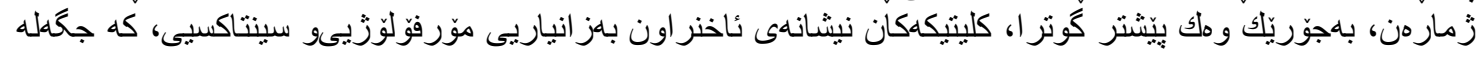

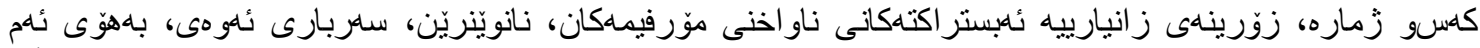

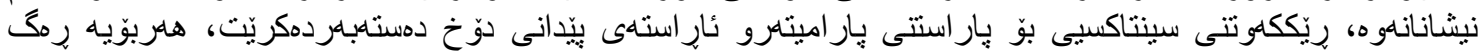

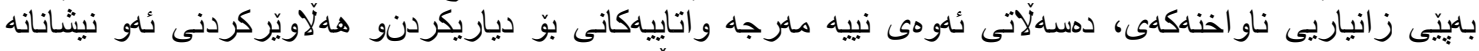

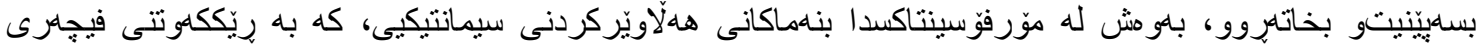

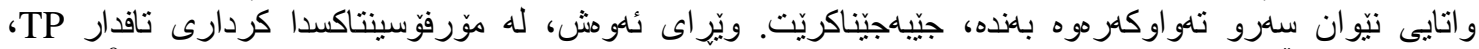

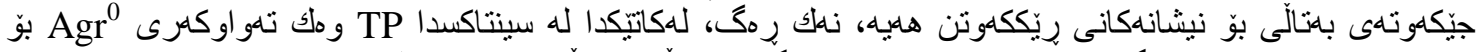

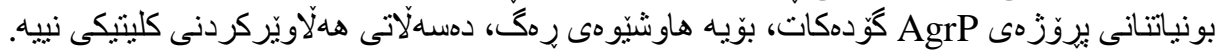

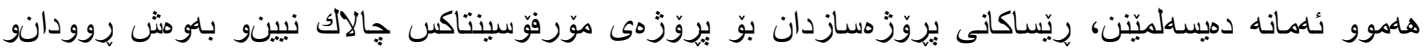

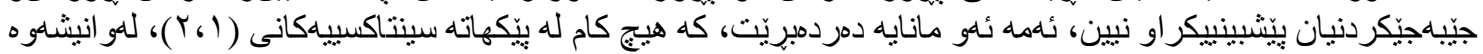

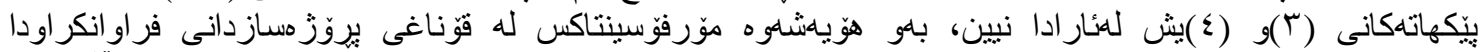

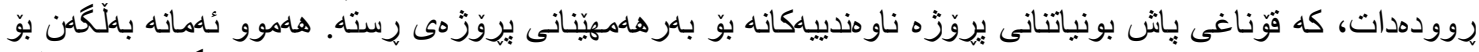

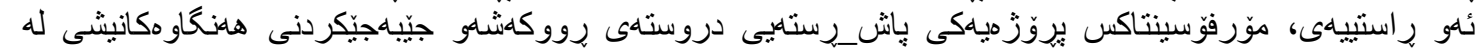

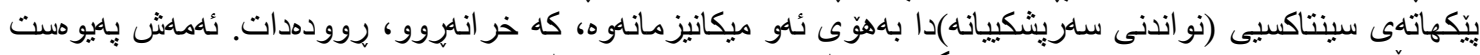

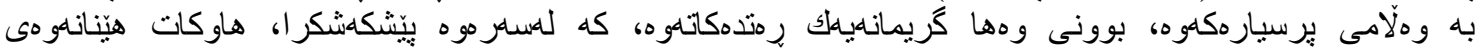
International Journal of Kurdish Studies Vol.4/1 ( January 2018) 


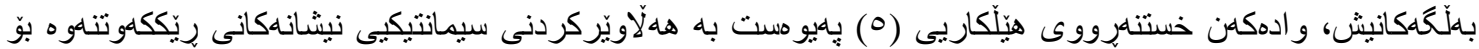

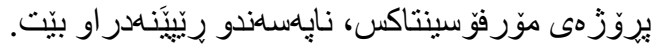

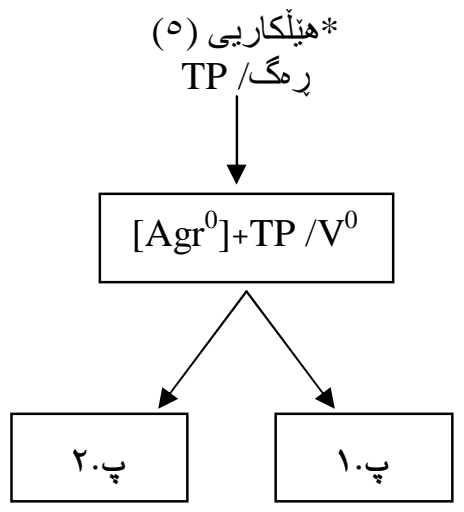

1/ آ دوّخ له دروستهى موّرفوّسينتاكسدا:

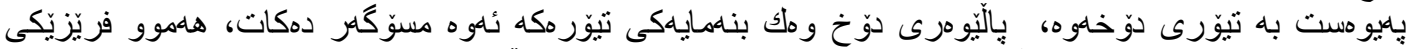

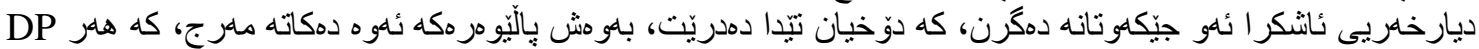

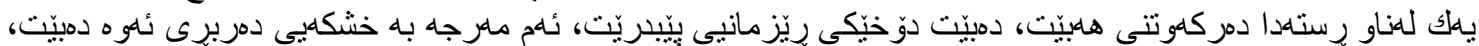

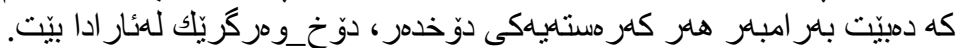

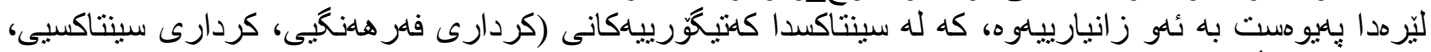

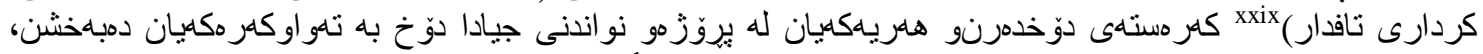

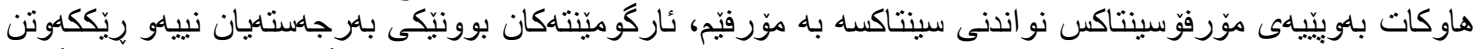

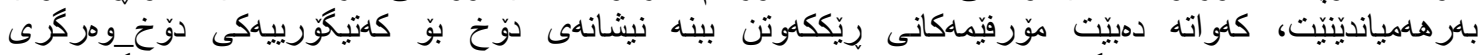

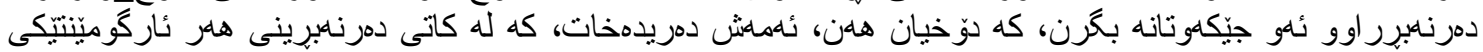

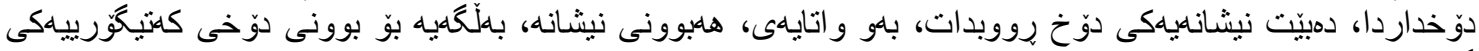

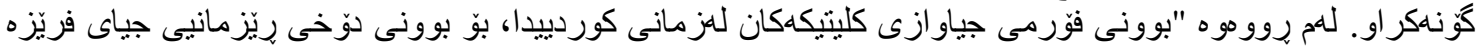

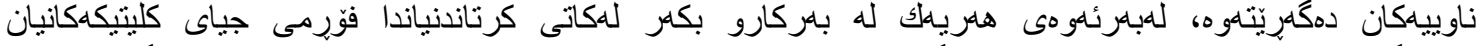

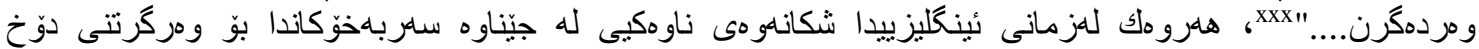

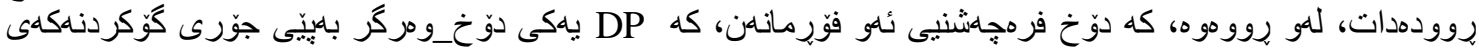

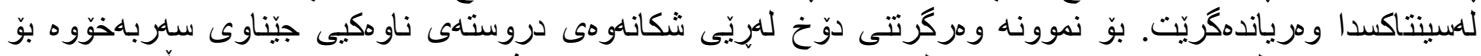

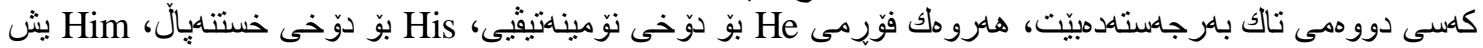

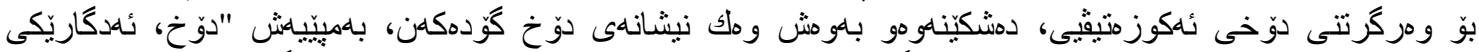

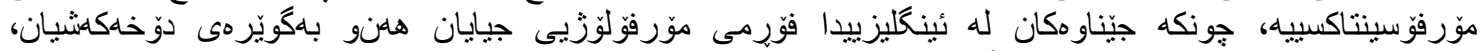

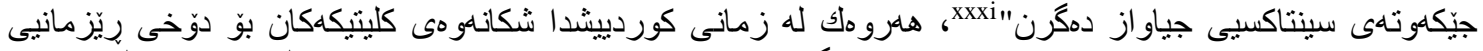

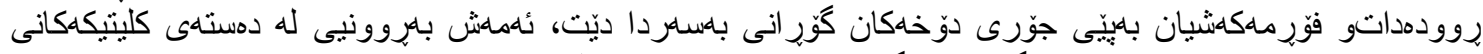

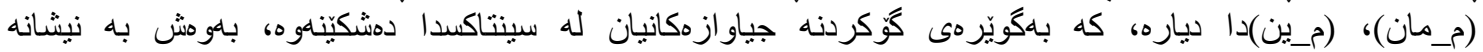

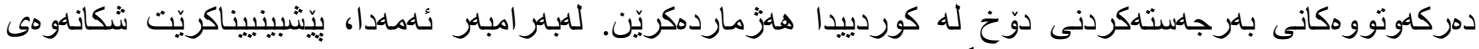

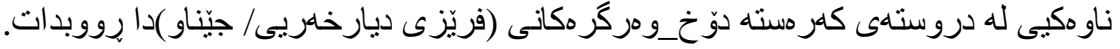

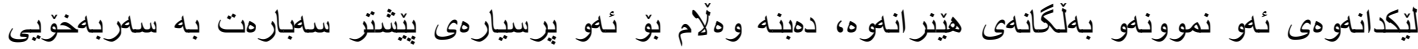

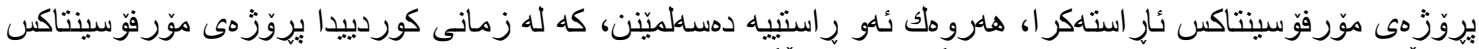

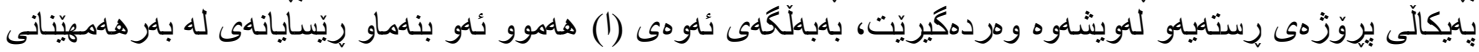

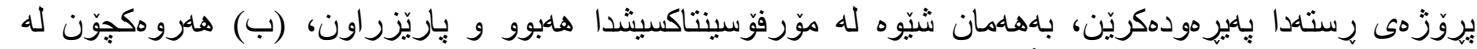

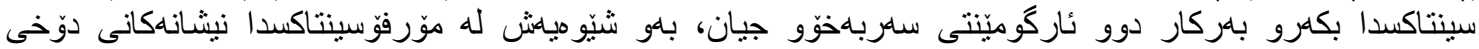

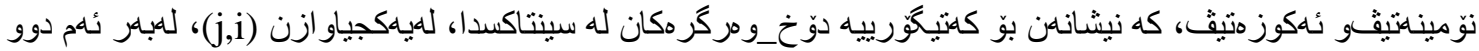

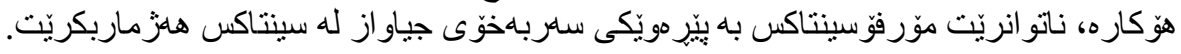

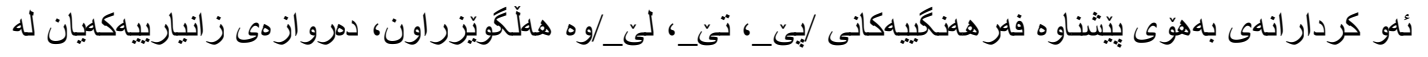




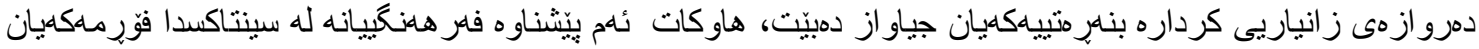

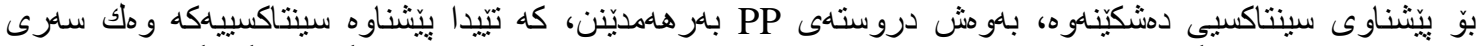

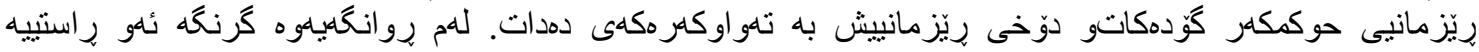

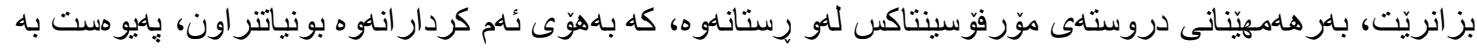

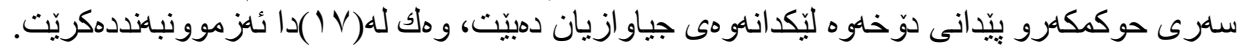

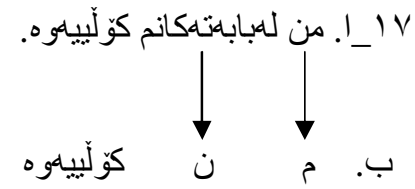

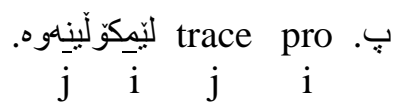

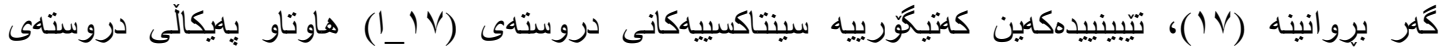

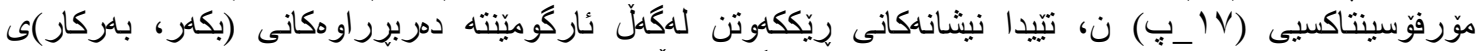

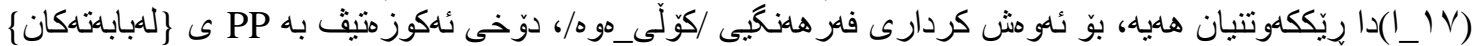

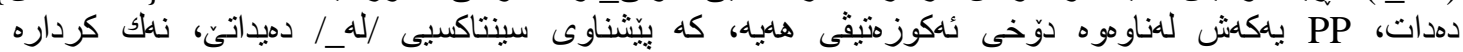

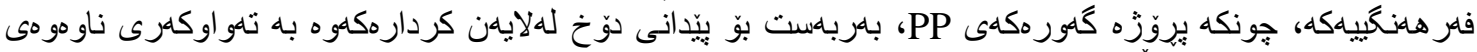

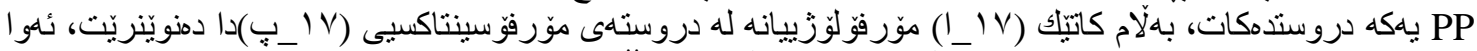

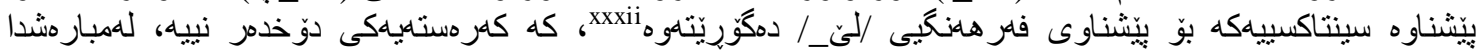

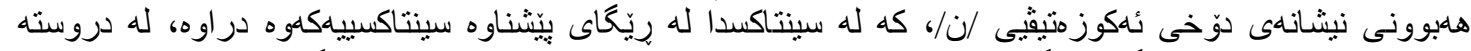

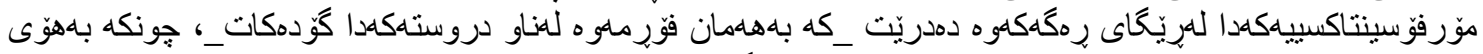

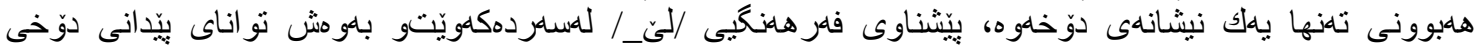

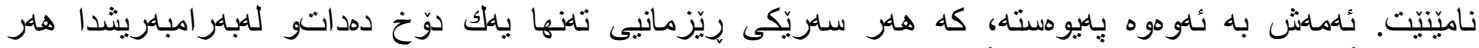

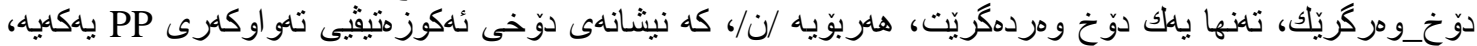

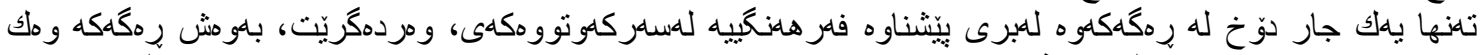

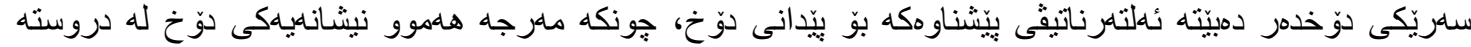

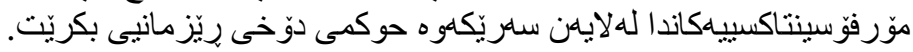

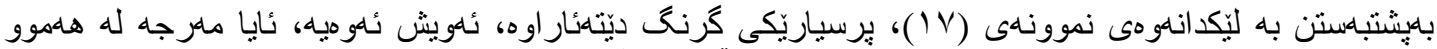

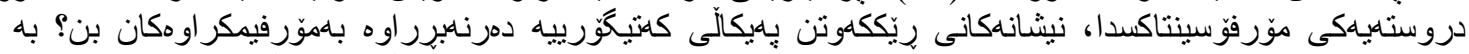

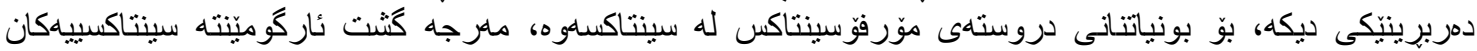

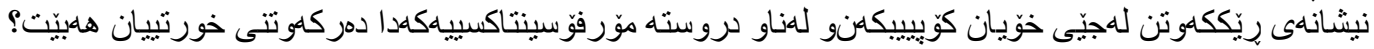

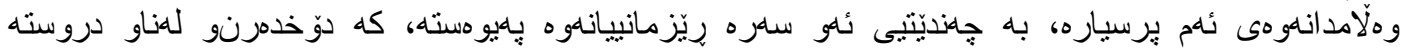

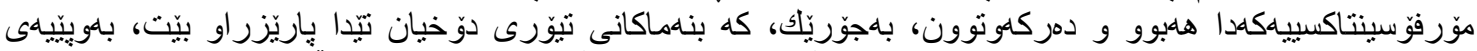

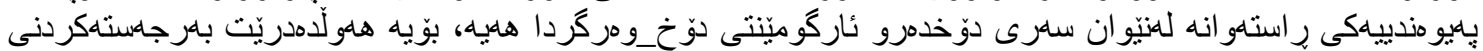

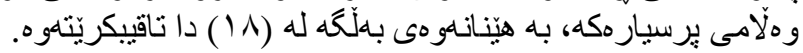

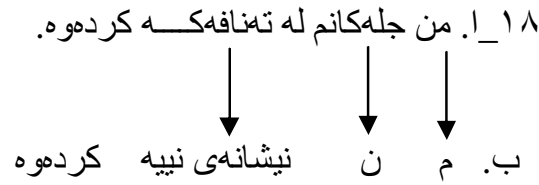

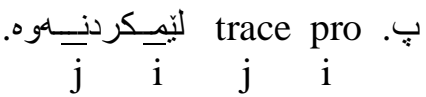

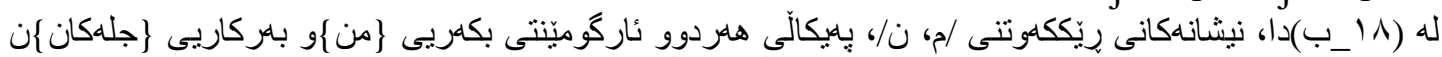

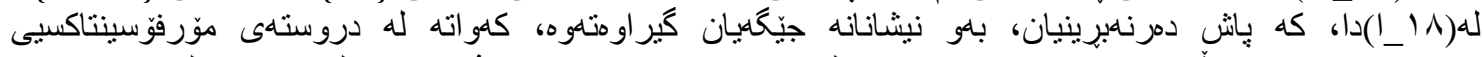

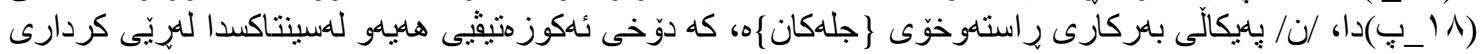

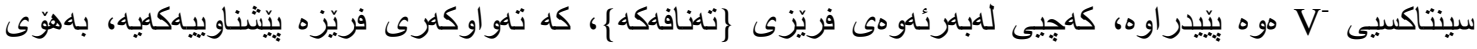
International Journal of Kurdish Studies Vol.4/1 ( January 2018 ) 


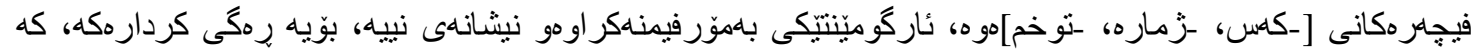

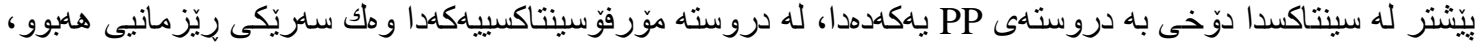

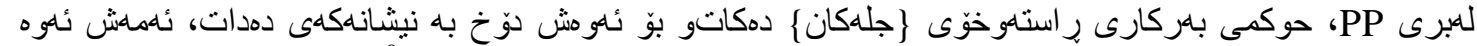

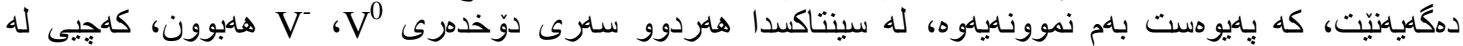

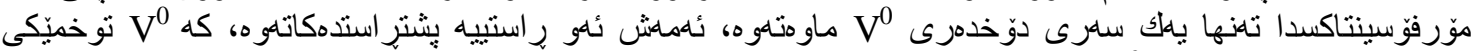

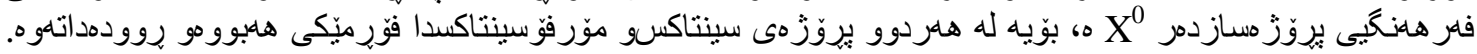

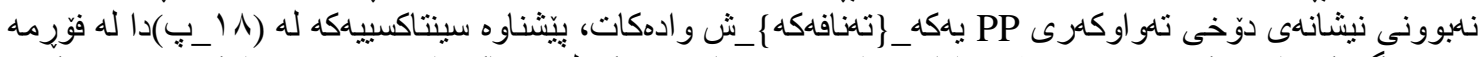

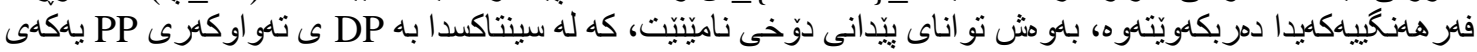

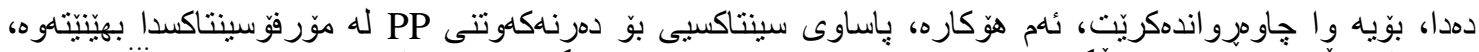

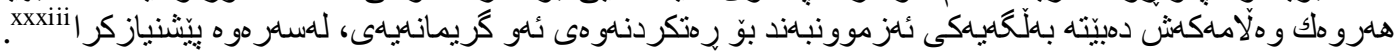

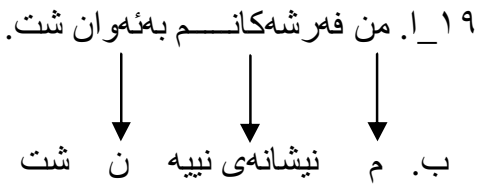

$\underset{j}{\mathrm{j}} \underset{\mathrm{i}}{\mathrm{i}} \mathrm{j} \quad \mathrm{j}$ trace pro

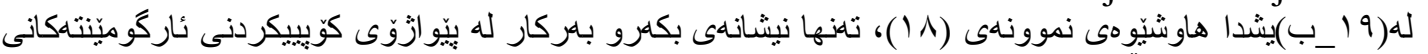

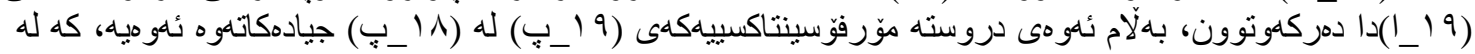

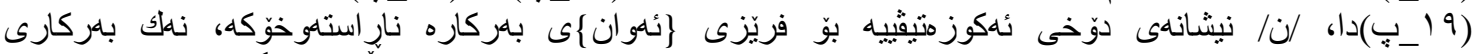

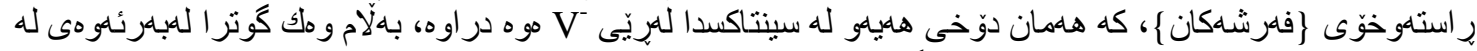

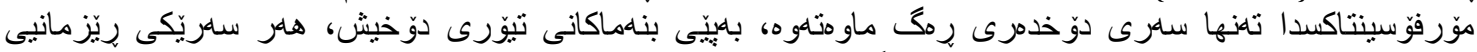

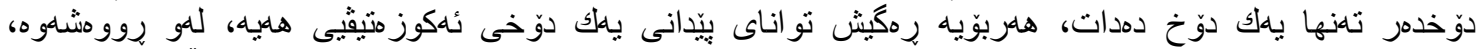

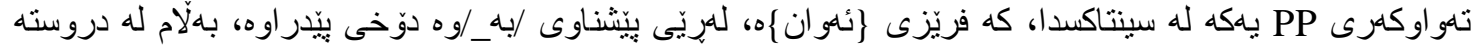

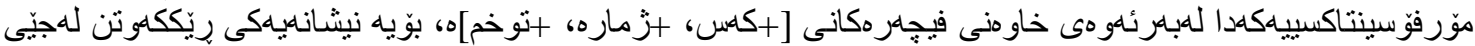

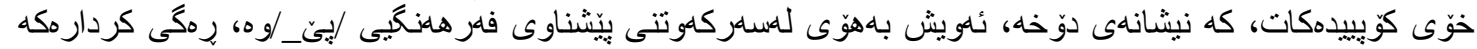
حوكميدكاتو دوَخى دهداتئ.

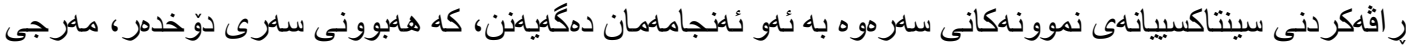

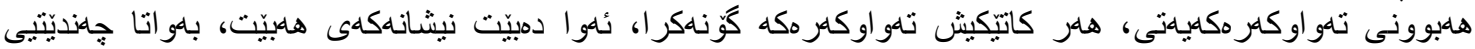

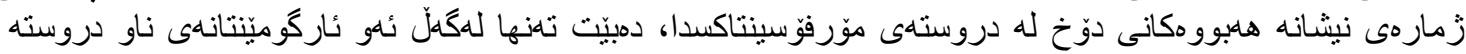

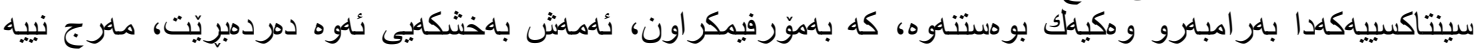

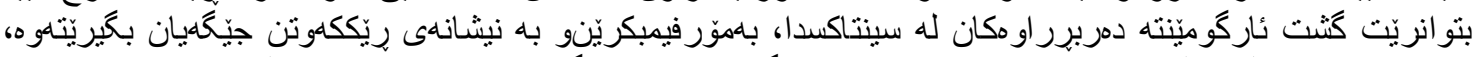

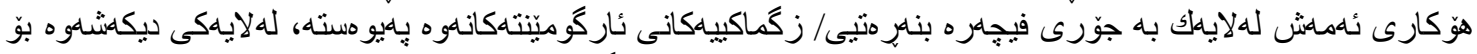

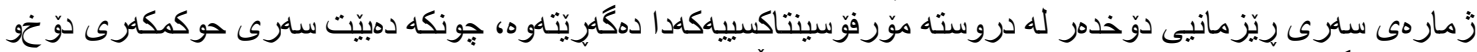

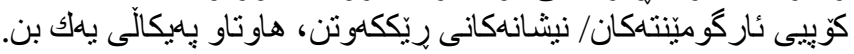

\section{ئنجام}

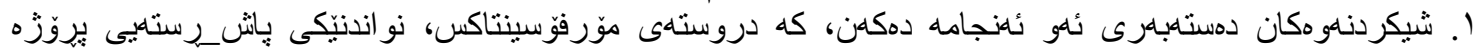

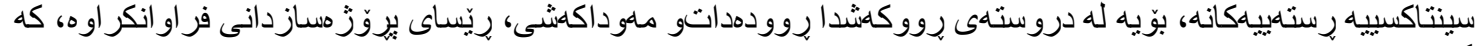

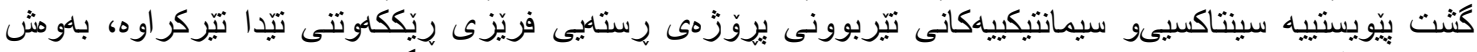

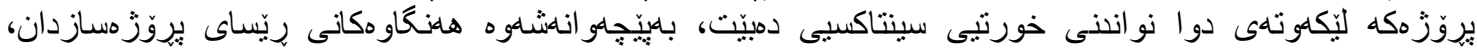

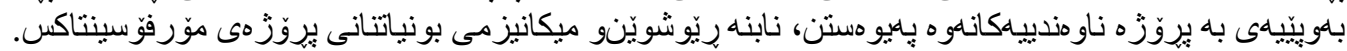

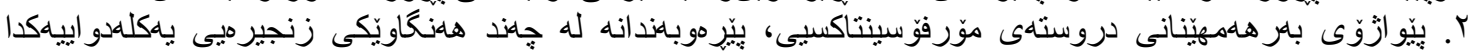

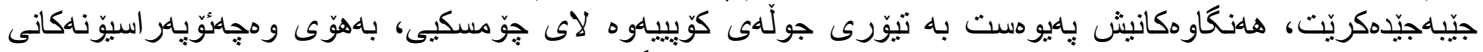

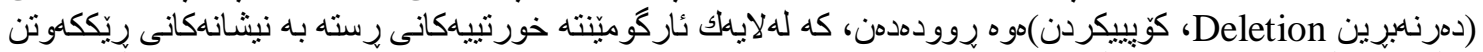

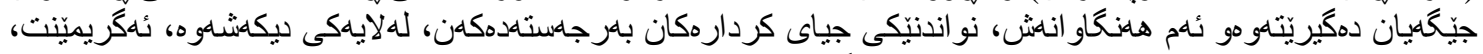

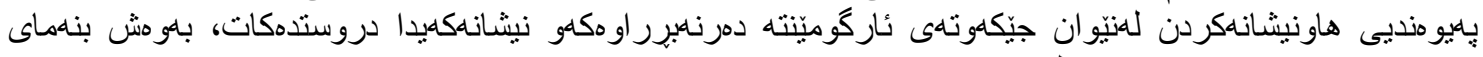

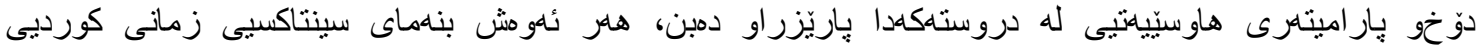
دمستهبلردمكات. 


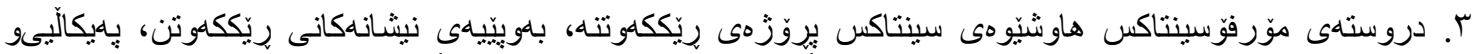

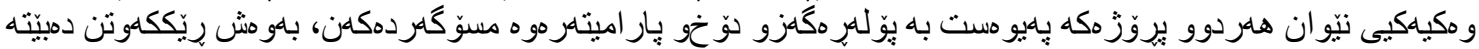

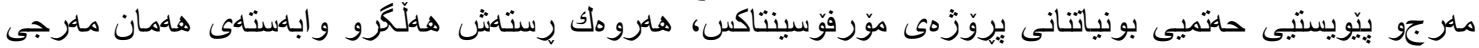
خورثيى سينتاكسيبه.

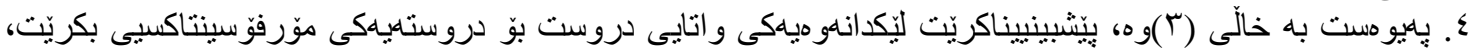

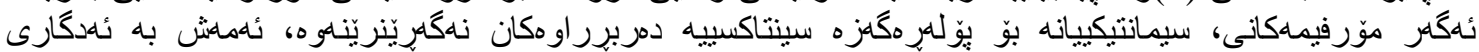

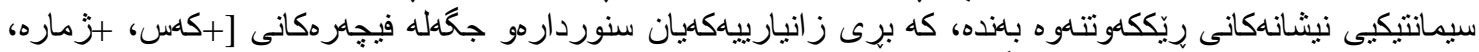

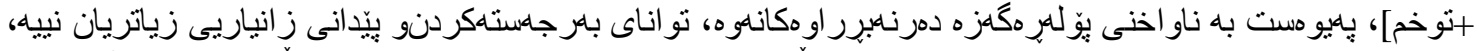

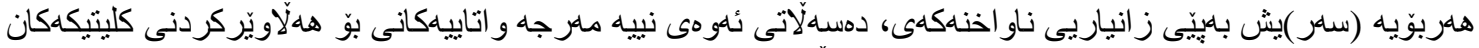

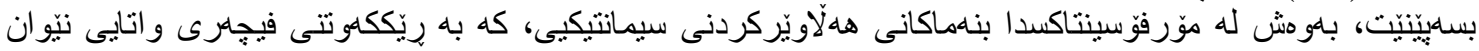

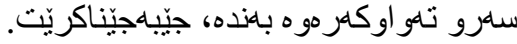

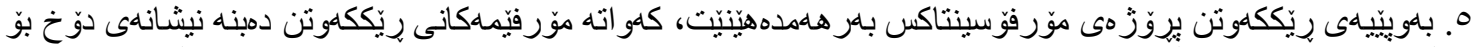

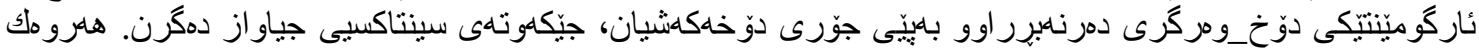

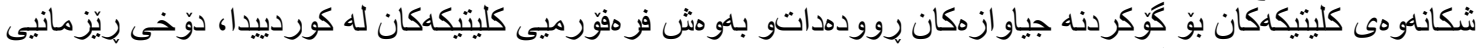

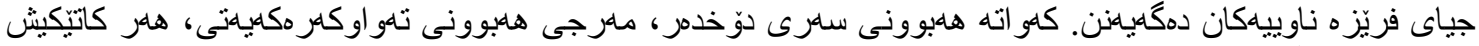

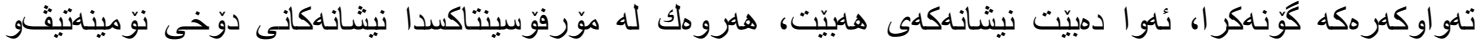

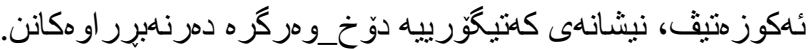

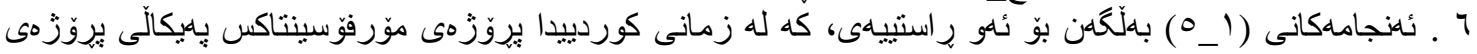

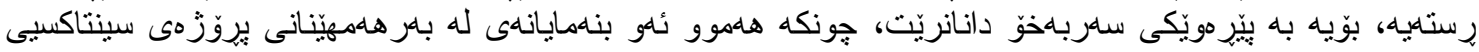

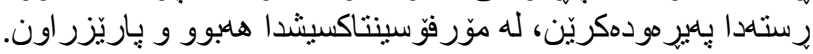

ليستى زاراوهكان

\begin{tabular}{|c|c|}
\hline & 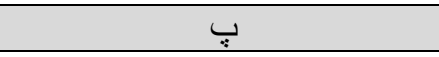 \\
\hline Agreement parameter & يِار اميتهرى ريّككهوتن \\
\hline Subjucency parameter & يار اميتهرى هاوسيّيهنيّي \\
\hline Post sentence & باءث ريته يى \\
\hline Projection Principle & رِيْساى يِروَزْه سازدان \\
\hline Extended Projection Principle & يرِّسـاى يِروّز سـاز دانى فر او انكر او \\
\hline Syntactical Sub categorization & يوّل لهر مكازز دياريكردنى سينتاكسيى \\
\hline Lexical Sub categorization & 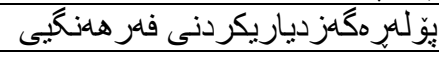 \\
\hline \multirow[t]{2}{*}{ Pre sentence } & يبى يِيش_رسته \\
\hline & $ت$ \\
\hline \multirow[t]{2}{*}{ Copy theory } & تيوّرى كوّيِيى \\
\hline & ج \\
\hline \multirow[t]{2}{*}{ Movement } & جو لُّندن \\
\hline & د \\
\hline \multirow[t]{2}{*}{ Morphosyntax structure } & دروستامى موّرفوّسينتاكس \\
\hline & س \\
\hline Functional heads & ساهر ه ئدركييهكان \\
\hline \multirow[t]{2}{*}{ Lexical head } & سارى فهر هلنغيي \\
\hline & ف \\
\hline \multirow[t]{2}{*}{ Functional phrase } & فريَزى ئه ركيى \\
\hline & 3 \\
\hline \multirow[t]{2}{*}{ Transformation } & كو استناهوه \\
\hline & $\dot{ن}$ \\
\hline Representation & 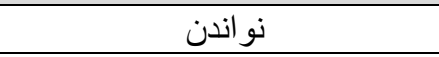 \\
\hline Syntactic representation & نو اندنى سينتاكسيى \\
\hline
\end{tabular}

International Journal of Kurdish Studies Vol.4/1 ( January 2018) 


\begin{tabular}{|c|c|}
\hline Case marker & نيشـانهى دوّ خ \\
\hline & $\Delta$ \\
\hline Semantic selection & ههلّاويّركردنى سيمانتيكيى \\
\hline & s \\
\hline Deletion rules & ياساكانى دهرنهبرين \\
\hline
\end{tabular}

ليستى كورتكر اودكان

\begin{tabular}{|c|c|}
\hline iيشانه & $\dot{u}$ \\
\hline Agreement & Agr. \\
\hline Agreement phrase & AGRP \\
\hline Determiner phrase & DP \\
\hline Object & Obj. \\
\hline Object agreement & Obj agr \\
\hline Subject & Sub. \\
\hline Subject agreement & Sub agr \\
\hline Tense & $\mathrm{T}^{0}$ \\
\hline Tense phrase & TP \\
\hline Lexical Verb & $\mathrm{V}^{0}$ \\
\hline Syntactic Verb & $\mathrm{V}^{-}$ \\
\hline Verb phrase & $\mathrm{VP}$ \\
\hline
\end{tabular}

سلرجهاو وكان

بليفزمانى كوردى:

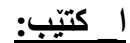

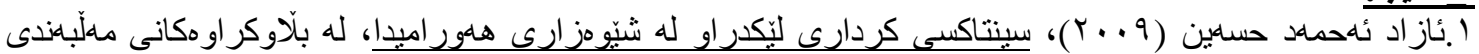

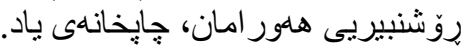

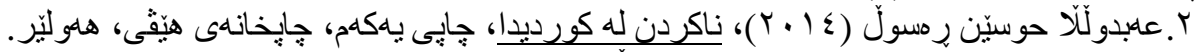

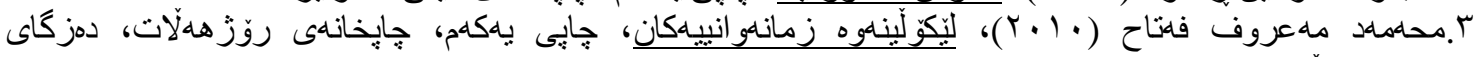

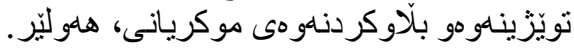

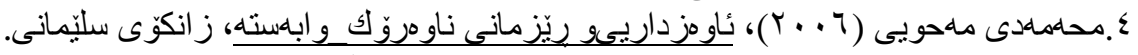

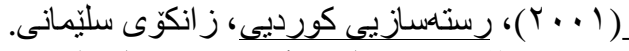
.0

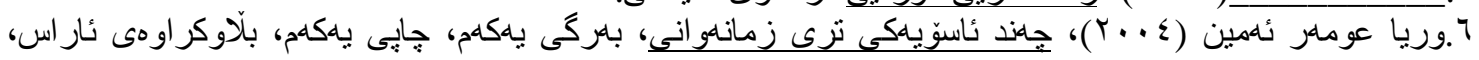

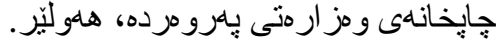

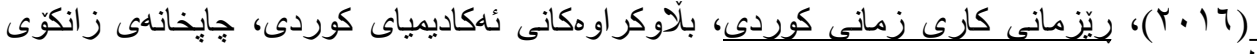

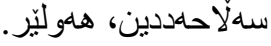

بـ بامهى زانكوّيع (بلّاونهكر اوه):

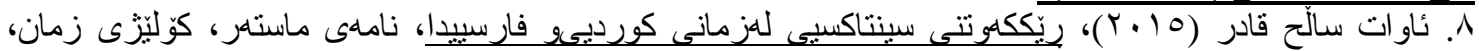

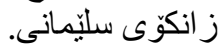

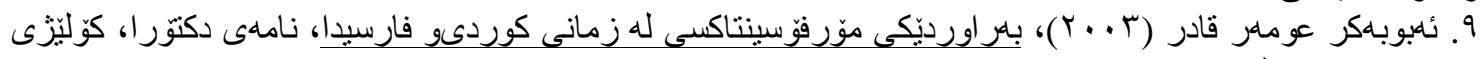

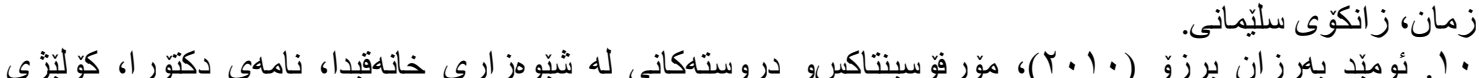

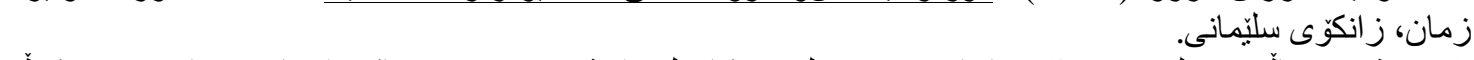

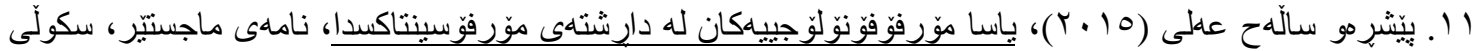

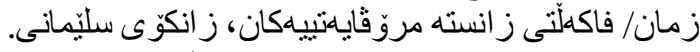

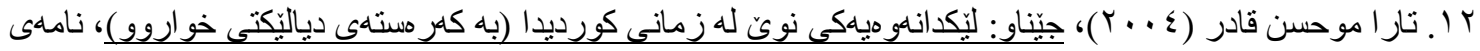
International Journal of Kurdish Studies Vol.4/1 ( January 2018) 


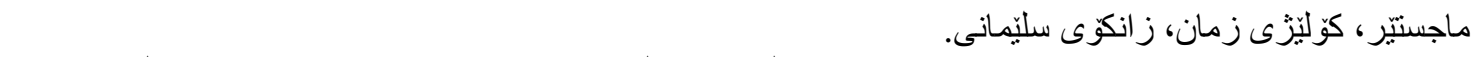

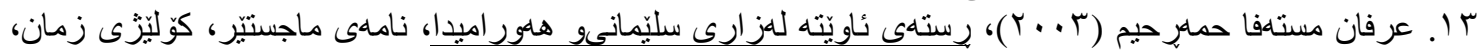

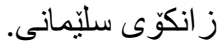

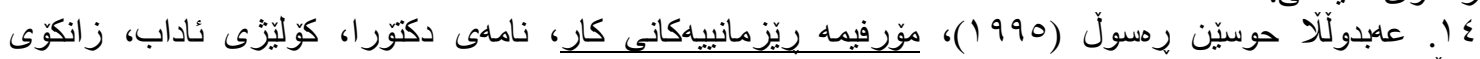

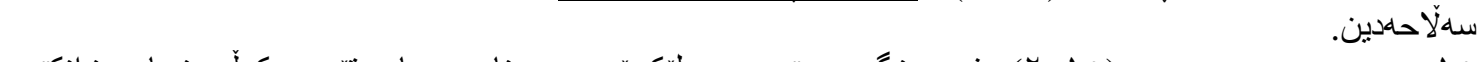

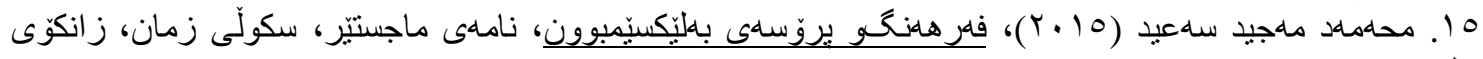

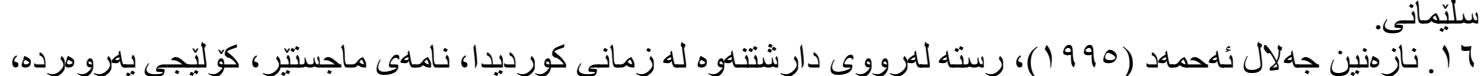
ز زانكوّى بهغدا.

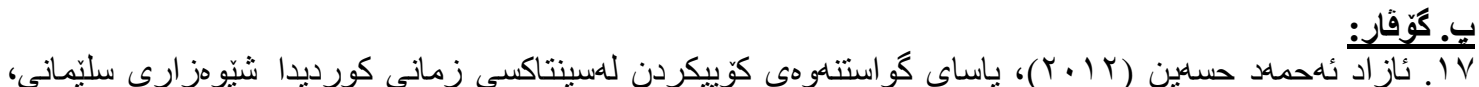

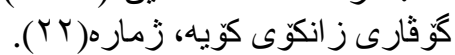

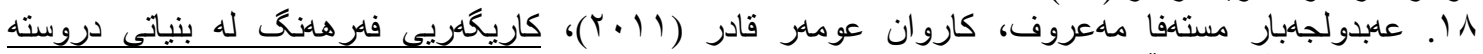

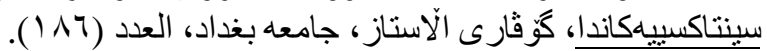

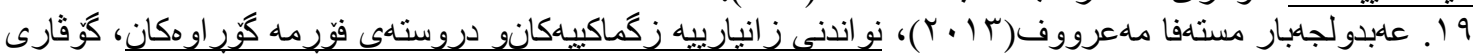

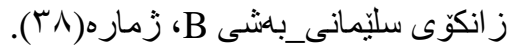

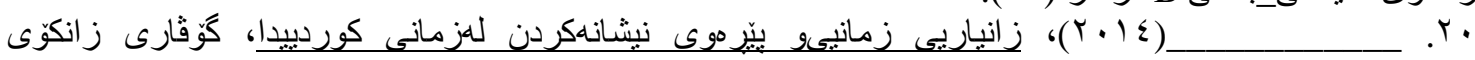

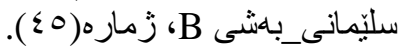

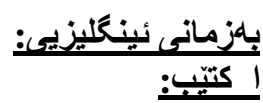

21.Cook. V. \& Newson, M. (1997), Chomsky's Universal Grammar, second edition, Blackwell Publishers.

22. Bobaljik, J. D. (1995), MORPHOSYNTAX: THE SYNTAX OF VERBAL INFLECTION, Massachusetts Institute of Technology .

23. Bussmann, H. T: Trauth, G. \& Kazzazi, K. (2006), Routledge Dictionary of Language and Linguistics, Taylor \& Francis

24.Kang, D. (2005), Scrambling in Universal Grammar: an analysis of scrambling as optional movement in Korean and other languages, Institut fuer Linguistik/Anglistik der Universitaet Stuttgart.

25. Radford, A. (2012), AN INTRODUCTION TO ENGLISH SENTENCE STRUCTURE, First published, CAMBRIDGE UNIVERSITY PRESS.

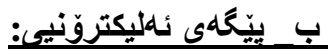
26. Kobele, G. M / http://home.uchicago.edu/ gkobele/files/Kobele10AAbar.pdf 27-Bošković, Ž. \& Nunes, J. / http://web.uconn.edu/boskovic/papers/Boskovic

Nunes-2007.pdf

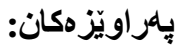

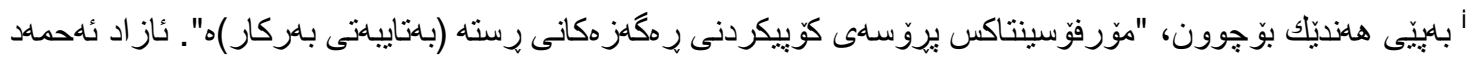

حساهين (T) "ii

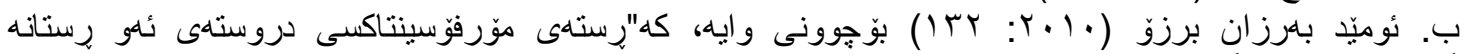

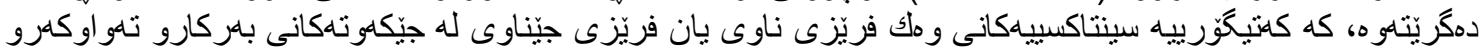

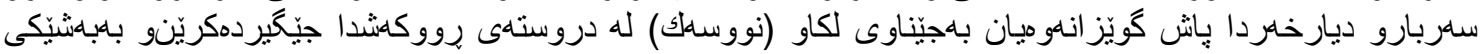

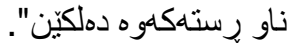

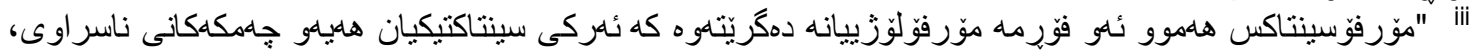

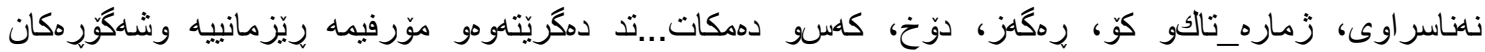
International Journal of Kurdish Studies Vol.4/1 ( January 2018 ) 
(Inflectional morphemes)

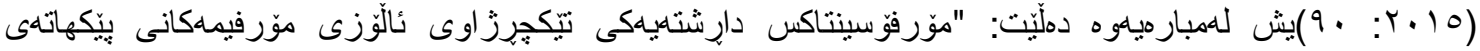

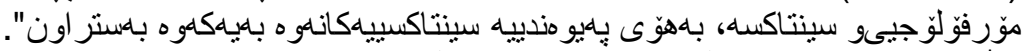

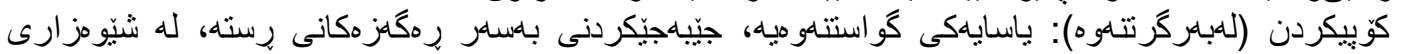

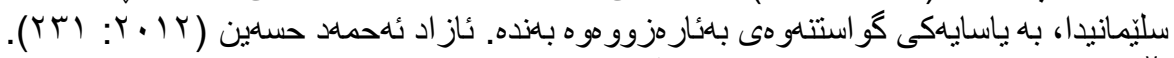

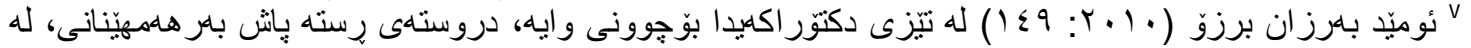

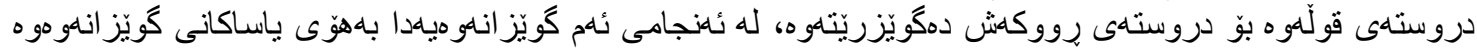
عالجار Transformational rules

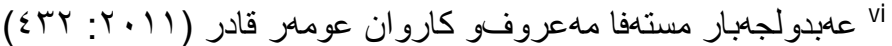

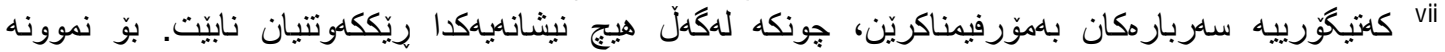

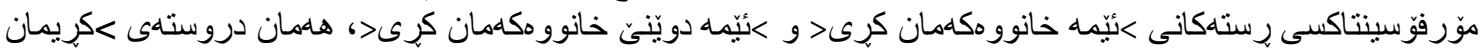

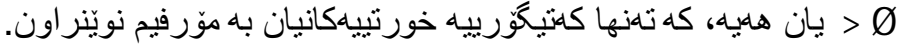

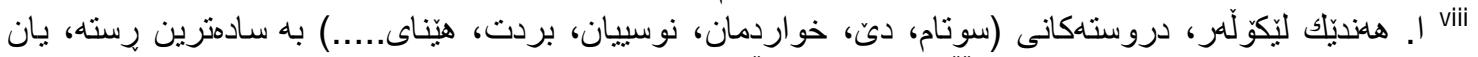

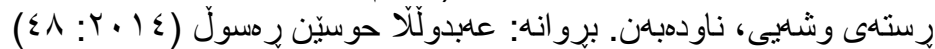

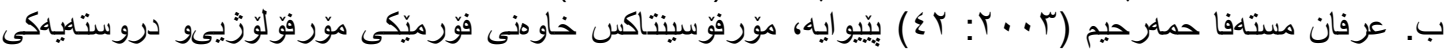

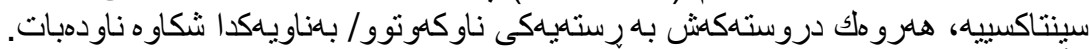

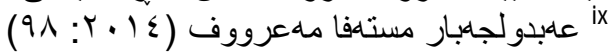

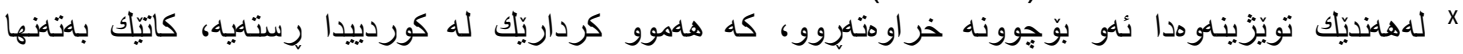

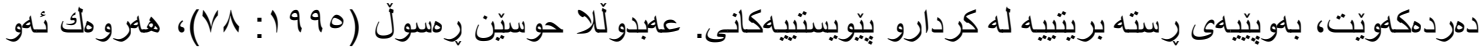

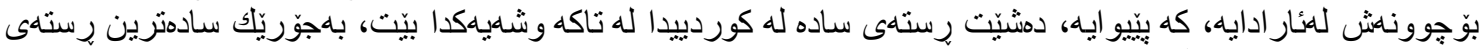

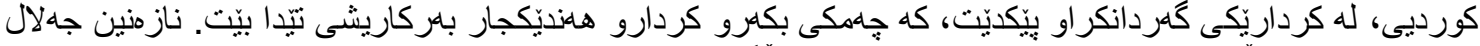

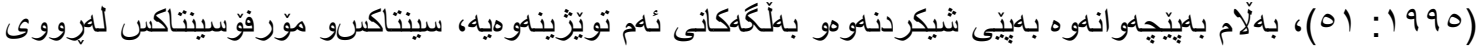

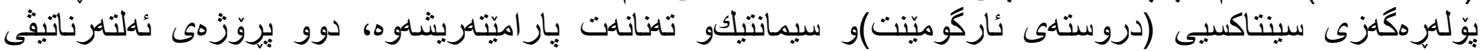

ياكترن.

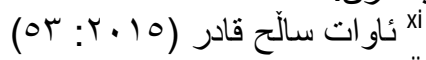

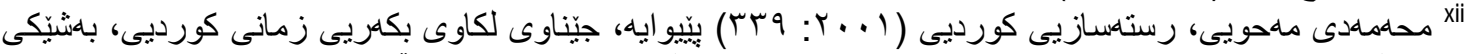

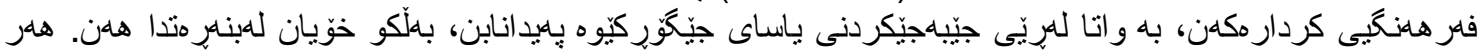

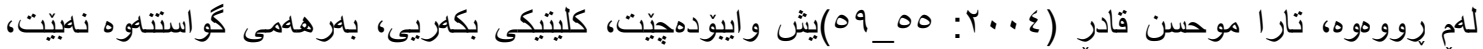

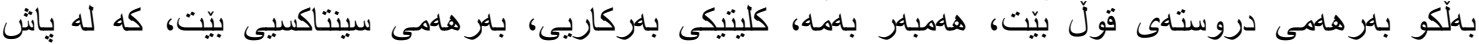

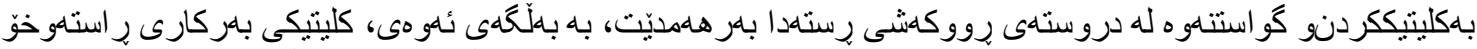

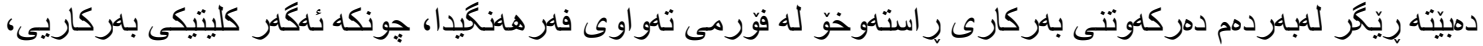

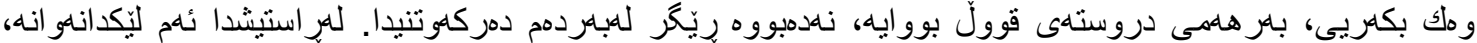

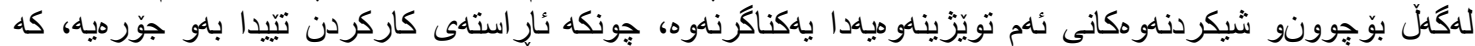

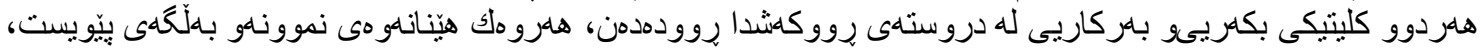

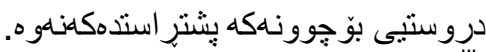
xili

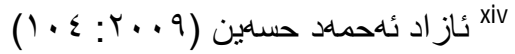

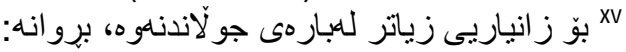

Kobele, G. M/ http://home.uchicago.edu/ gkobele/files/Kobele10AAbar.pdf

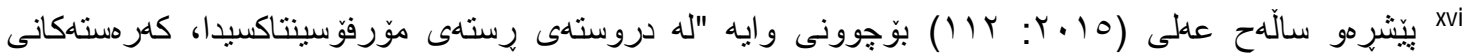

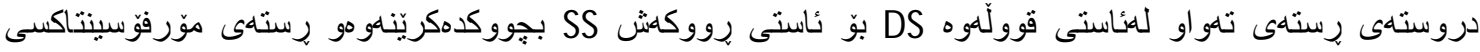
لتيّدروستدمكريتي".

xvii

(a) Baltin, M. (2010: 1) / https://as.nyu.edu/content/dam/nyu-

as/faculty/documents/baltin_copytheoryofmovement.pdf

(b) Bošković, Ž. \& Nunes, J. / http://web.uconn.edu/boskovic/papers/Boskovic-Nunes2007.pdf

International Journal of Kurdish Studies Vol.4/1 ( January 2018) 
xviii Radford, A. (2012: 125)

xix ibed, 394

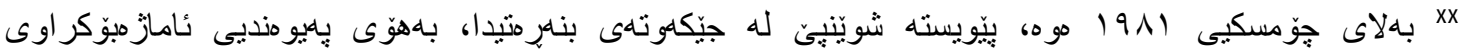

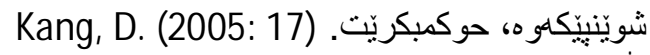

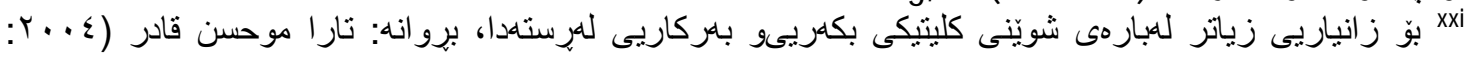

100 of

xxii Cook, V. \& Newson, M. (1997: $\overline{194)}$

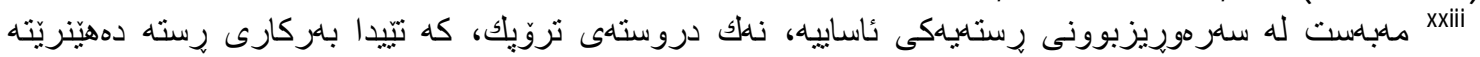

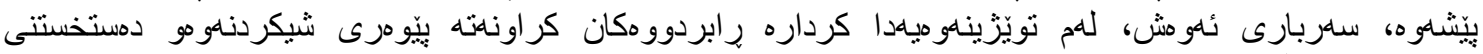

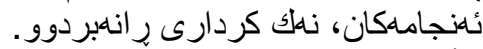

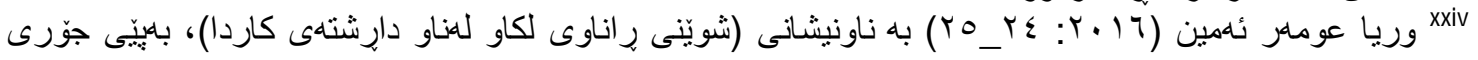

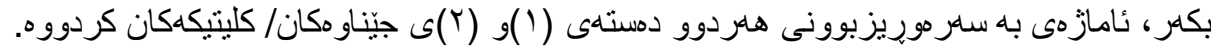

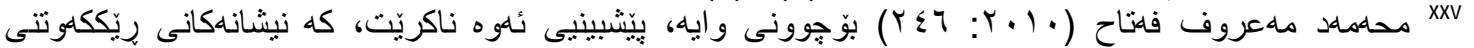

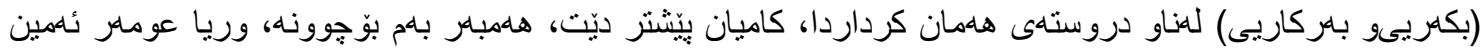

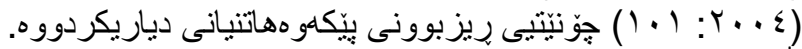
مxvi

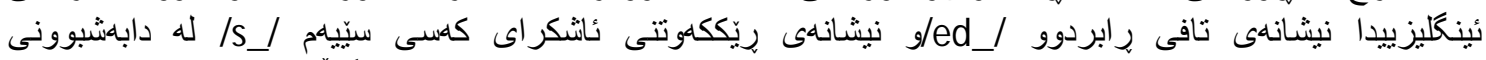

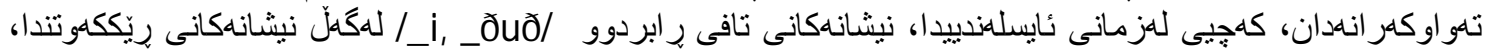

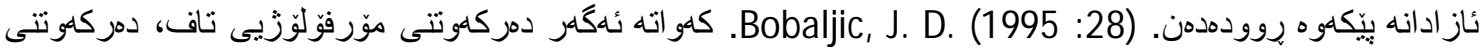

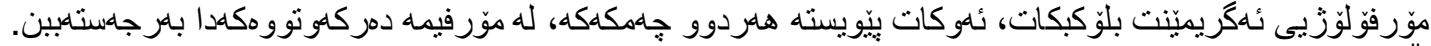
XXVii

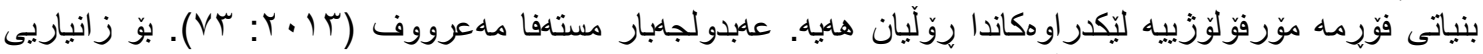

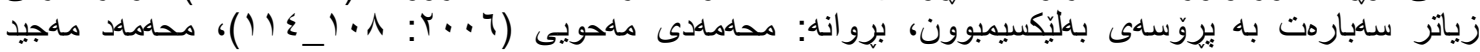

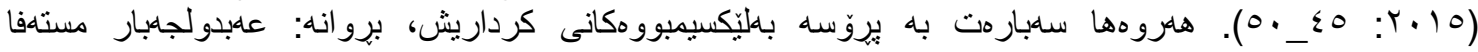

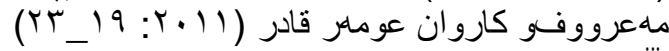
ئار ام روشيد مهجيد (T Xxviii

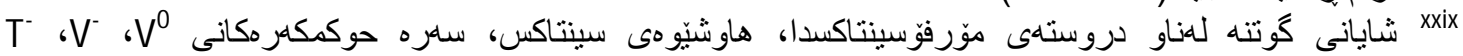

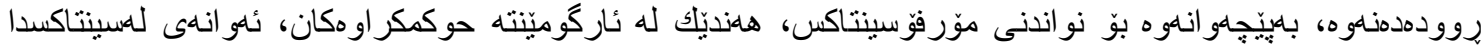

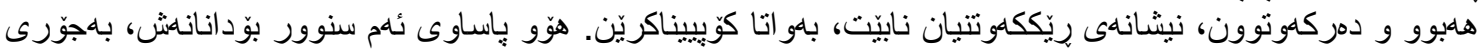

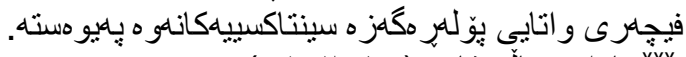

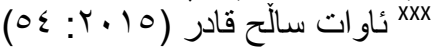

xxxi Radford, A. (2012: 394)

xxxii

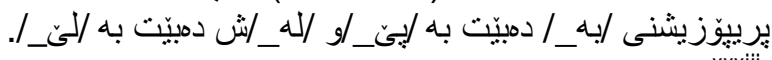

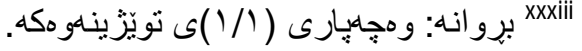

